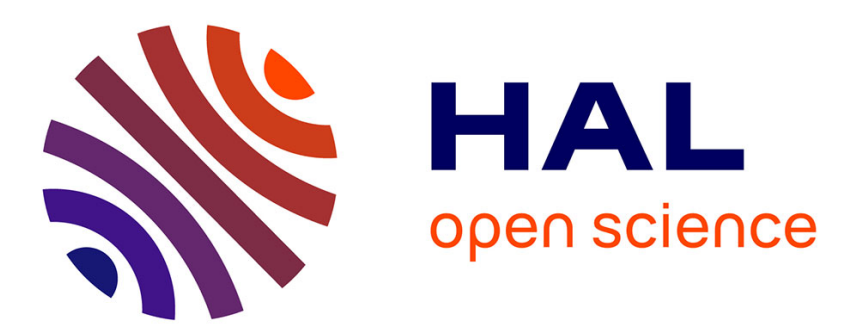

\title{
The 2007Stromboli eruption: Event chronology and effusion rates using thermal infrared data
}

S. Calvari, L. Lodato, A. Steffke, A. Cristaldi, Andrew J.L. J.L. Harris, L. Stampinato, E. Boschi

\section{- To cite this version:}

S. Calvari, L. Lodato, A. Steffke, A. Cristaldi, Andrew J.L. J.L. Harris, et al.. The 2007Stromboli eruption: Event chronology and effusion rates using thermal infrared data. Journal of Geophysical Research : Solid Earth, 2010, 115, pp.B04201. 10.1029/2009JB006478 . hal-00530870

\section{HAL Id: hal-00530870 https://hal.science/hal-00530870}

Submitted on 11 Oct 2021

HAL is a multi-disciplinary open access archive for the deposit and dissemination of scientific research documents, whether they are published or not. The documents may come from teaching and research institutions in France or abroad, or from public or private research centers.
L'archive ouverte pluridisciplinaire HAL, est destinée au dépôt et à la diffusion de documents scientifiques de niveau recherche, publiés ou non, émanant des établissements d'enseignement et de recherche français ou étrangers, des laboratoires publics ou privés.

$$
\text { Copyright }
$$




\title{
The 2007 Stromboli eruption: Event chronology and effusion rates using thermal infrared data
}

\author{
S. Calvari, ${ }^{1}$ L. Lodato, ${ }^{1}$ A. Steffke,${ }^{2}$ A. Cristaldi, ${ }^{1}$ A. J. L. Harris, ${ }^{3}$ L. Spampinato, ${ }^{1}$ \\ and $\mathrm{E} . \mathrm{Boschi}^{1}$ \\ Received 23 March 2009; revised 14 October 2009; accepted 25 November 2009; published 21 April 2010.
}

[1] Using thermal infrared images recorded by a permanent thermal camera network maintained on Stromboli volcano (Italy), together with satellite and helicopter-based thermal image surveys, we have compiled a chronology of the events and processes occurring before and during Stromboli's 2007 effusive eruption. These digital data also allow us to calculate the effusion rates and lava volumes erupted during the effusive episode. At the onset of the 2007 eruption, two parallel eruptive fissures developed within the northeast crater, eventually breaching the NE flank of the summit cone and extending along the eastern margin of the Sciara del Fuoco. These fed a main effusive vent at $400 \mathrm{~m}$ above sea level to feed lava flows that extended to the sea. The effusive eruption was punctuated, on 15 March, by a paroxysm with features similar to those of the 5 April paroxysm that occurred during the 2002-2003 effusive eruption. A total of between $3.2 \times 10^{6}$ and $11 \times 10^{6} \mathrm{~m}^{3}$ of lava was erupted during the 2007 eruption, over 34 days of effusive activity. More than half of this volume was emplaced during the first 5.5 days of the eruption. Although the 2007 effusive eruption had an erupted volume comparable to that of the previous (20022003) effusive eruption, it had a shorter duration and thus a mean output rate (=total volume divided by eruption duration) that was 1 order of magnitude higher than that of the 20022003 event $\left(\sim 2.4\right.$ versus $\left.0.32 \pm 0.28 \mathrm{~m}^{3} \mathrm{~s}^{-1}\right)$. In this paper, we discuss similarities and differences between these two effusive events and interpret the processes occurring in 2007 in terms of the recent dynamics witnessed at Stromboli.

Citation: Calvari, S., L. Lodato, A. Steffke, A. Cristaldi, A. J. L. Harris, L. Spampinato, and E. Boschi (2010), The 2007 Stromboli eruption: Event chronology and effusion rates using thermal infrared data, J. Geophys. Res., 115, B04201, doi:10.1029/2009JB006478.

\section{Introduction}

[2] Typical eruptive activity at Stromboli (Aeolian Islands, Italy; Figures 1a and $1 \mathrm{~b}$ ) consists of persistent, mildly explosive events occurring every 5 to $20 \mathrm{~min}$. Typically, these Strombolian events erupt small volumes of ejecta to heights of between 150 and $300 \mathrm{~m}$ above the active vents [Harris and Ripepe, 2007a] (Figures 1c and 1d). The summit crater area (the crater terrace) is an elliptical depression $\sim 300 \mathrm{~m}$ long and $\sim 50 \mathrm{~m}$ wide (Figure 1c). The crater terrace is at $\sim 750 \mathrm{~m}$ above sea level (asl), which places it $\sim 170 \mathrm{~m}$ below Il Pizzo (918 m asl; Figure 1c). The crater terrace comprises three craters, whose geographic position has remained remarkably constant over at least 100 years [e.g., Washington, 1917; Calvari et al.,

\footnotetext{
${ }^{1}$ Istituto Nazionale di Geofisica e Vulcanologia, Sezione di Catania, Catania, Italy.

${ }^{2}$ Hawaii Institute of Geophysics and Planetology/School of Ocean and Earth Science and Technology, University of Hawaii, Honolulu, Hawaii, USA.

${ }^{3}$ Laboratoire Magmas et Volcans, Université Blaise Pascal, Clermont Ferrand, France.

Copyright 2010 by the American Geophysical Union. 0148-0227/10/2009JB006478
}

2005a, 2005b; Harris and Ripepe, 2007a]. Effusive eruptions at this volcano have a frequency of 5 to 15 years [Barberi et al., 1993], with lava flows erupted during the last two millennia being confined to the Sciara del Fuoco (SDF), a collapse scar on the NW flank of the volcano (Figures 1b and 1c).

[3] Since 2001 the monitoring of effusive and explosive eruptions at Stromboli has increasingly involved the use of thermal imagery obtained from handheld thermal infrared cameras. Data collected from fixed stations and helicopterbased surveys have played four roles. First, they have allowed checking of the temperature variations at, as well as the number, position, and morphology of active vents within, the crater terrace [Calvari et al., 2005a, 2005b; Burton et al., 2008], as well as the location and opening of eruptive fractures [Ripepe et al., 2009]. Second, they have allowed mapping of active lava flow fields and the development of lava flow features [Calvari et al., 2006; Lodato et al., 2007]. Third, they have been used to derive heat fluxes and effusion rates during effusive events [Harris et al., 2005b; Calvari et al., 2005a, 2005b; Lodato et al., 2007]. Fourth, they have been used to study the eruption dynamics during persistent explosive activity [Harris and Ripepe, 2007a; Patrick, 2007; 


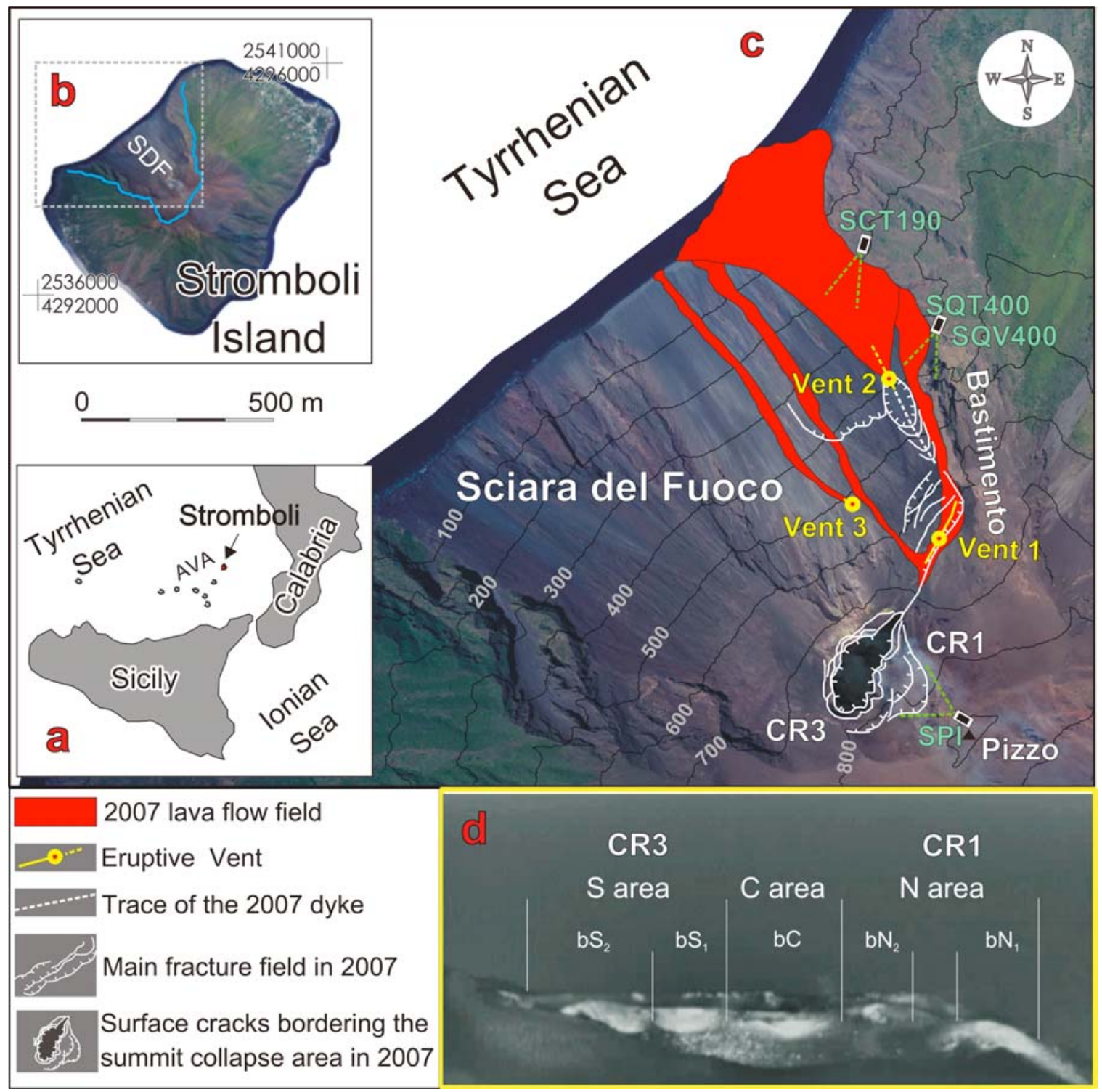

Figure 1. (a) Location of the Aeolian Volcanic Arc (AVA) and Stromboli. (b) Island of Stromboli, with the outline of the Sciara del Fuoco (SDF) marked by the blue line. The area enlarged in Figure 1c is also located. (c) The 2007 lava flow field (in red), with the feeding vents (in yellow) and location of the Istituto Nazionale di Geofisica e Vulcanologia, Sezione di Catania (INGV-CT), Web cameras: SPI (Stromboli infrared thermal camera at Il Pizzo), SQT400 (Stromboli infrared thermal camera at $400 \mathrm{~m}$ elevation), SQV400 (Stromboli visible camera at $400 \mathrm{~m}$ elevation), and SCT190 (Stromboli infrared thermal camera at $190 \mathrm{~m}$ elevation). CR1 and CR3 mark the SW and NE craters. (d) Position of the active vents within the crater terrace as could be seen from the SPI camera located at Il Pizzo, where S, C, and N mark the SW, central and NE craters, respectively, within which $\mathrm{bS}_{2}, \mathrm{bS}_{1}, \mathrm{bC}, \mathrm{bN}_{2}$, and $\mathrm{bN}_{1}$ locate the active vents within each crater as of February 2007. (Images in Figures 1a to 1c are courtesy of M. Neri (modified after Neri and Lanzafame [2009])).

Patrick et al., 2007; Zanon et al., 2009], gas puffing [Harris and Ripepe, 2007b], and paroxysms [Calvari et al., 2006; Harris et al., 2008].

[4] Thermal cameras were used for the first time during an effusive event at Stromboli during the 2002-2003 eruption. This eruption produced a number of phenomena such as tsunami [Bonaccorso et al., 2003; Tinti et al., 2005], sliding of portions of the SDF [Tommasi et al., 2008], flank collapses and opening of fractures and eruptive vents [Bonaccorso et al., 2003; Calvari et al., 2005a, 2005b], paroxysmal explosive events [Calvari et al., 2006; Rosi et al., 2006; Harris et al., 2008], and emplacement of compound lava flow fields on steep slopes [Calvari et al., 2005a, 2005b; Lodato et al., 2007; Spampinato et al., 2008a]. The later stages of the eruption were characterized by low effusion rates (typically $<1 \mathrm{~m}^{3} \mathrm{~s}^{-1}$ [Calvari et al., 2005a, 2005b; Harris et al., 2005b; Lodato et al., 2007]) and a transition back to the typical strombolian activity experienced by Stromboli [Ripepe et al., 
2005]. As a result of the 2002-2003 event, monitoring systems deployed on the volcano were significantly expanded to allow improved forecasting capabilities in the event of new and potentially dangerous eruptive events. Consequently, instrumentation was in place and operational at the onset of the 2007 effusive event.

[5] The 2007 eruption began on 27 February 2007, lasted 34 days, until 2 April, and has previously been the topic of a Journal of Volcanogical and Geothermal Research special issue [Scandone et al., 2009] in which Barberi et al. [2009] provided a chronological overview of events. In this paper we discuss the dynamics of Stromboli's 2007 effusive eruption, providing a chronology of the events based on qualitative and quantitative analyses of thermal infrared images recorded by fixed Web cameras operated by the Istituto Nazionale di Geofisica e Vulcanologia, Sezione di Catania (INGV-CT). Lava effusion rate is also a key parameter when forecasting maximum lava flow length and estimating volcanic hazard [e.g., Kilburn, 1993; Calvari and Pinkerton, 1998; Harris and Rowland, 2009], as well as in assessing the depressurization state and eruption mechanisms operating during an effusive eruption [e.g., Wadge, 1981; Harris et al., 2000; Rowland et al., 2003]. We thus also present effusion rates calculated from thermal images acquired using Forward Looking Infrared (FLIR) spectrometer thermal infrared cameras, as well as those estimated using two satellite-based sensors: the Advanced Very High Resolution Radiometer (AVHRR) and the Moderate Resolution Imaging Spectroradiometer (MODIS).

\section{Istituto Nazionale di Geofisica e Vulcanologia, Sezione di Catania, Thermal Camera Monitoring System at Stromboli}

[6] During and following Stromboli's 2002-2003 effusive eruption, the INGV-CT thermal monitoring system was greatly improved. As a result, during the 2007 effusive eruption, we were able to collect a high-temporal-resolution thermal data set to allow assessment of the daily variation in eruptive events from the onset of the eruption. Here we describe the camera network installed on Stromboli, the instrument characteristics and methodology, and the use of helicopter- and satellite-based thermal imaging. All data were then used for near-real-time thermal surveillance of the eruptive events.

\subsection{Web-Camera Network}

[7] Prior to 2002, the INGV-CT camera network consisted of a visual camera located at Il Pizzo, a location at $918 \mathrm{~m}$ asl that overlooks the crater terrace (Figure 1c). From this location the camera captured images of the entire crater terrace ( $\sim 170 \mathrm{~m}$ below the camera location) over a downwardlooking line of sight with a camera-to-target distance of between 250 and $300 \mathrm{~m}$ (Figures 1c and 1d). This enabled imaging of the explosive events, estimation of the height attained by the products to a maximum limit of $\sim 200 \mathrm{~m}$ (the upper limit of the image field of view (FOV)), and discrimination between predominant ejecta types (ash, lapilli, bombs, and blocks). Between the end of the 2002-2003 effusive eruption and the onset of the 2007 eruption, the INGV-CT visual monitoring system was greatly improved by the installation of four additional cameras. These included one visual camera and one Stromboli thermal infrared camera at Il Pizzo (SPI), plus one Stromboli visual camera (SQV400) and one Stromboli thermal infrared camera (SQT400) at the $400 \mathrm{~m}$ elevation. The latter two cameras were located on the eastern flank of the SDF, $\sim 800 \mathrm{~m}$ from the crater terrace. From this location the cameras provided a view of the NE crater and the eastern sector of the SDF (Figure 1c). This location is crucial because the eruptive fissures that opened during the last four effusive episodes (1975, 1985-1986, 2002-2003, and 2007) breached the NE flank of the crater terrace [Capaldi et al., 1978; De Fino et al., 1988; Calvari et al., 2005a, 2005b; Marchetti et al., 2009] and thus fed activity in this sector. Additionally, on 12 March 2007, while lava effusion was still ongoing, a fifth Stromboli thermal infrared camera was installed on the eastern margin of the $\mathrm{SDF}$ at the $190 \mathrm{~m}$ elevation (SCT190; Figure 1c). From this location the number and position of active lava flows, as well as the development of lava flow field features, could be tracked.

[8] The thermal SPI camera is an OPGAL EYE-M320B, and the SQT400 is a FLIR ThermoVision 320M. Both cameras are sensitive across the 8 to $14 \mu \mathrm{m}$ wave band and have an uncooled microbolometer as the detector. Although they both give $320 \times 240$ pixel images, which we sample every $2 \mathrm{~s}$, the SPI has a $60^{\circ} \times 45^{\circ} \mathrm{FOV}$ and the SQT400 has a $24^{\circ} \times 18^{\circ} \mathrm{FOV}$. These correspond to pixel sizes of $\sim 0.2 \mathrm{~m}$ over a minimum distance of $250 \mathrm{~m}$ (for the SPI) and $1.1 \mathrm{~m}$ at a distance of $800 \mathrm{~m}$ (for the SQT400). The thermal infrared camera installed at the $190 \mathrm{~m}$ elevation (SCT190) was a FLIR A40. This gives an inclined view of the SDF and the zone of effusive vents over a mean distance of $300 \mathrm{~m}$. The main difference between the OPGAL camera and the two FLIR cameras is that the OPGAL camera provides just a visual representation of the thermal infrared energy, whereas the FLIR cameras provide radiometric information; that is, data are calibrated so that temperature information can be extracted for each pixel. All images also record the date in the format $\mathrm{dd} / \mathrm{mm} / \mathrm{yy}$ and the time in the format hh:mm:ss. All times are given in UTC.

\subsection{Handheld Thermal Imagery}

[9] Ground-based thermal imaging was first used at Stromboli by Dehn et al. [2001] during a preliminary deployment at Il Pizzo in 2001. Further deployments proceeded campaign style, with cameras being deployed for a few days every year between 2001 and 2004 to examine the dynamics of the Strombolian eruptions [Patrick et al., 2007]. With the onset of the 2002-2003 effusive eruption, as during the 2007 eruption, thermal surveys were performed daily using a FLIR S65 thermal infrared camera during helicopter flights organized by Protezione Civile Regione Siciliana and Protezione Civile Nazionale. These 2002-2003 helicopterbased deployments are described by Calvari et al. [2005a, 2005b], Harris et al. [2005b], and Lodato et al. [2007]. During the 2007 eruption such helicopter-based surveys occurred on at least a daily basis between 27 February 2007 and 6 May 2007.

[10] Like the permanently installed FLIR thermal infrared cameras, the S65 model used for the helicopter-based surveys consists of an uncooled microbolometer detector array sensitive across the 8 to $14 \mu \mathrm{m}$ wave band. It has an $18^{\circ} \times 24^{\circ}$ lens and provides $320 \times 240$ pixel images at up to 60 frames 
per second. The stated precision of the instrument is $\pm 2 \%$, and the thermal sensitivity is $<0.08^{\circ} \mathrm{C}$ at $30^{\circ} \mathrm{C}$. The $\mathrm{S} 65$ is equipped with an extra filter to detect maximum temperatures up to $1500^{\circ} \mathrm{C}$ and can record data in one of three temperature ranges: $-40^{\circ}$ to $120^{\circ} \mathrm{C}, 0^{\circ}$ to $500^{\circ} \mathrm{C}$, and $350^{\circ}$ to $1500^{\circ} \mathrm{C}$. The camera software completes internal calibration and atmospheric correction, so that input emissivity, path length, air temperature, and relative humidity allow output of apparent temperatures corrected for emissivity and atmospheric effects. While atmospheric parameters and path length are routinely measured during each thermal survey, we used an emissivity of 0.95 , a value that is typical for basalt at Stromboli in the 8 to $14 \mu \mathrm{m}$ wave band [Harris and Stevenson, 1997]. On the basis of thermal measurements made during effusive eruptions at Etna, as well as on Stromboli during 2002-2003, we performed thermal surveys early in the morning to avoid solar heating problems [Calvari and Pinkerton, 2004], tried to capture images from the zenith position [Ball and Pinkerton, 2006], and repeated the same flight path everyday so as to obtain images that had comparable geometries [Calvari et al., 2005a, 2005b; Harris et al., 2005b]. Corrections resulting from pixel size differences due to varying distances to the target, estimated from the difference between the helicopter location obtained using onboard GPS and the locations of known ground-control points, were applied following Harris et al. [2005b]. The method of Harris et al. [2005b] was also applied to estimate effusion rates from the thermal camera data. Apparent temperatures will still be affected by the presence of aerosols, volcanic gases, and airborne volcanic ash along the path length. This will result in an error in the estimate of the true surface temperature [Calvari et al., 2005a, 2005b; Sawyer and Burton, 2006; Spampinato et al., 2008b; L. Spampinato et al., Revisiting the use of infrared thermal cameras for the surveillance of active volcanoes, submitted to EarthScience Reviews, 2009].

\subsection{Advanced Very High Resolution Radiometer and Moderate Resolution Imaging Spectroradiometer Satellite Thermal Data}

[11] For satellite-derived effusion rates we have used data from AVHRR and MODIS, two sensors flown on polar orbiting satellites capable of detecting hot spots due to volcanic activity as well as providing data that can be applied to estimate the area, heat flux, and effusion rate of active lava flows [e.g., Harris et al., 1997; Wright et al., 2001; Hirn et al., 2009]. Both detectors have previously been used to provide effusion rates for the 1985-1986 and 2002-2003 effusive eruptions of Stromboli by Harris et al. [2000, 2005b], Calvari et al. [2005a, 2005b], Ripepe et al. [2005], and Lodato et al. [2007]. For effusion rate extraction all images were examined manually, so that radiances for all pixels identified as being thermally anomalous in images of suitable quality (no cloud cover) were extracted. Extracted radiances were then converted to effusion rate following the methodology of Harris et al. [1997] and as applied to AVHRR data for Stromboli by Harris et al. [2000] and Calvari et al. [2005a, 2005b]. The extraction process results in the generation of an effusion rate range for each image within which the true, field-measured, value usually lies (see Harris et al. [2007b] for a full review and assessment). Dragoni and
Tallarico [2009] have recently reviewed the assumptions underlying the relationship between effusion rate and heat flux, with Harris and Baloga [2009] clarifying the methodology and assumptions as applied to low-spatial-resolution satellite data. Following Wright et al. [2001] and Harris and Baloga [2009], the extracted value relates to a time-averaged value, not to an instantaneous (effusion rate) value, so that the time-averaged discharge rate is likely a better term for the derived value.

\section{Explosive Activity Between the 2002-2003 and the 2007 Effusive Eruptions}

[12] At the onset of the 2002-2003 effusive eruption, the floor of the crater terrace collapsed, leaving a $\sim 50 \mathrm{~m}$ deep elongate crater. Explosive activity died out at the crater terrace during the first 4 months of the 2002-2003 eruption, with the free surface and explosive activity recovering as the rate of effusion declined [Ripepe et al., 2005]. As a result, by the end of the 2002-2003 effusive eruption (in July 2003), strombolian activity had resumed at the crater terrace. Following the 2002-2003 effusive eruption, persistent explosive activity generated spatter, scoria, and ash that steadily filled the collapse feature that had formed at the onset of the 2002 2003 effusive event. Thus, the elongate crater evolved into a platform on which hornitos and cinder cones developed. To achieve this fill we estimate that an approximate volume of $1.5 \times 10^{6} \mathrm{~m}^{3}$ of material had to have been deposited between July 2003 and February 2007, resulting in a mean fill rate of $\sim 0.01 \mathrm{~m}^{3} \mathrm{~s}^{-1}$. It is worth noting that, as described in previous papers [e.g., Washington, 1917; Calvari et al., 2005a, 2005b; Harris and Ripepe, 2007a], the position of the active vents has remained almost constant during the last century, even after major morphological changes such as the collapse events of 2002-2003 and subsequent refilling by tephra.

[13] The rate of explosive activity, and hence filling of the collapse feature, was not constant with time. To obtain a semiquantitative description of the eruptive activity during this time, we used the images recorded by the SPI camera (which views the entire crater area) to calculate a daily mean for the number of explosions per hour. To do this we simply counted the total number of events observed during each day of cloud-free observation and divided by $24 \mathrm{~h}$. Figure 2 shows the pattern of explosive activity from 24 October 2003 until the onset of the 2007 eruption. The period between 17 September 2006 and 21 January 2007 lacks data, owing to camera malfunction. A few peaks, when the number of explosions reached 10 to 18 per hour, can be identified between the end of October 2003 and February 2004. After this we observe a stable level, with the number of explosions remaining below 10 per hour from the end of March 2004 until November-December 2004. During January 2005 the average number of explosions increased to between 25 and 30 per hour. Between March 2005 and the onset of the 2007 eruption, a general increasing trend in the number of explosions per hour can be observed. This is punctuated by five peaks, in December 2005, in January 2006, on 1 April 2006, on 15 July 2006, and on 16 February 2007. The number of explosions increased to a climax of between 25 and 30 explosions per hour 12 days before the start of the 2007 eruption (Figure 2). These values compare with a typical rate of eight or nine 


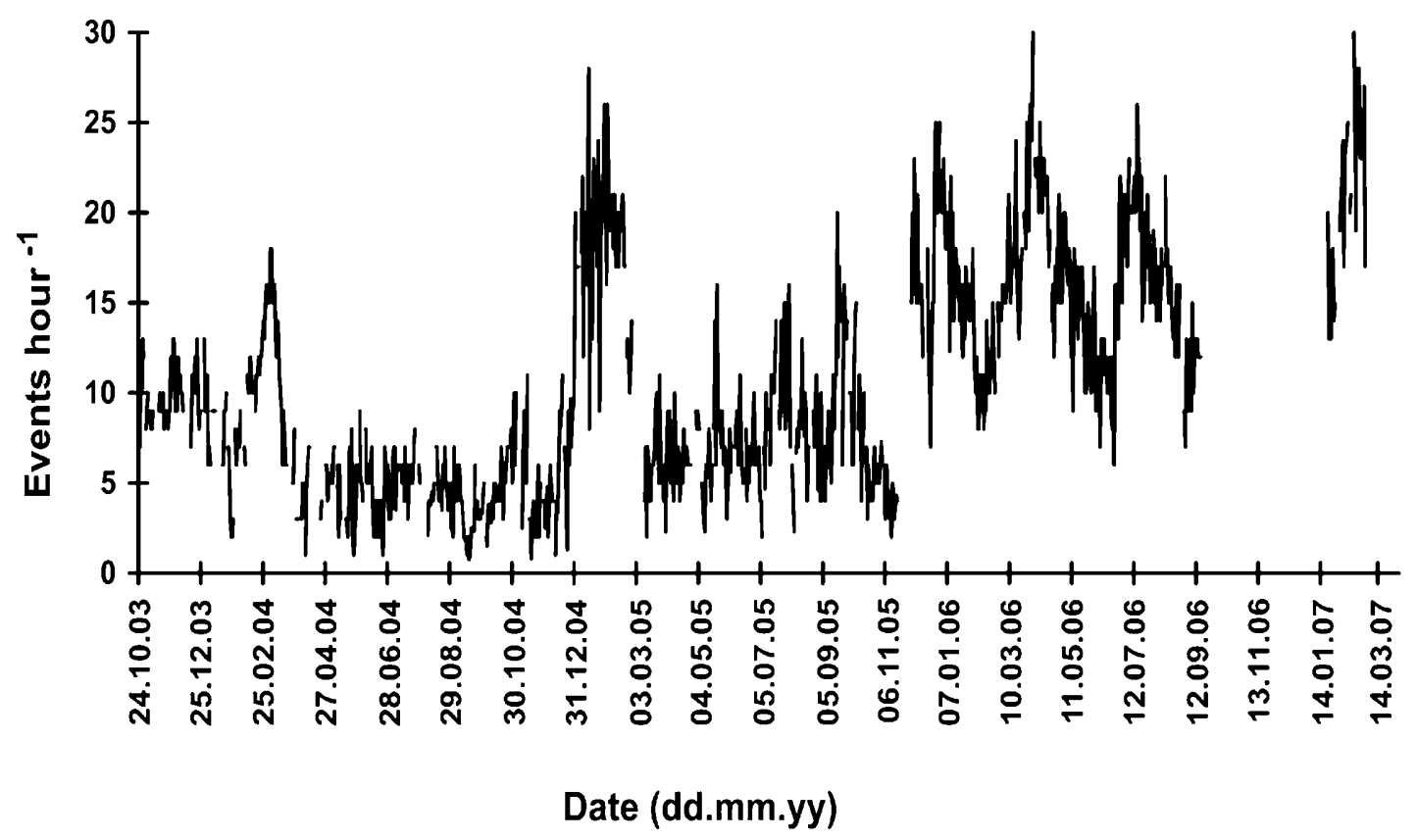

Figure 2. Graph showing the daily average frequency of explosions per hour at the crater terrace between 24 October 2003 and 27 February 2007, reconstructed using images recorded by the SPI camera (see Figure 1c for camera location).

explosions per hour [Harris and Ripepe, 2007a; Ripepe et al., 2009].

\section{Chronology of the Eruption}

\subsection{Onset of the 2007 Effusive Activity}

[14] Between the end of December 2006 and February 2007, an increase in volcanic tremor was recorded by the Osservatorio Vesuviano (INGV-OV) seismic network. In addition, the frequency of very long period seismic events increased, with event locations clustered at $\sim 200 \mathrm{~m}$ below the summit craters [Martini et al., 2007], a location typical for Stromboli [Chouet et al., 2003]. In January 2007, the groundbased linear interferometric synthetic aperture radar, installed on the eastern flank of the SDF, showed a progressive acceleration in the deformation on the NE crater [Casagli et al., 2009]. In addition, tremor, pressure recorded by infrasonic sensors, and number of explosive events per hour began to increase from January onward [Ripepe et al., 2009]. By the first half of February deformation had spread to involve also the upper portion of the SDF [Casagli et al., 2009].

[15] When the eruption began on 27 February 2007, the deformation rates recorded by the ground-based linear interferometric synthetic aperture radar were higher than the measurement capability of the radar device [Casagli et al., 2009]. At $\sim 0900$ on the same day and about $4 \mathrm{~h}$ before the start of the onset of effusive activity, the INGV-OV seismic network recorded several signals associated with landslides, sometimes superimposed on the volcanic tremor [Martini et al., 2007]. Landslides continued during the next few hours, and at 1239 a stronger landslide was recorded [Martini et al., 2007]. An effusive fracture was then observed to be opening within the northern rim of the NE crater at 1249, with the fracture quickly propagating NE [Marchetti et al., 2009]. An air-based thermal survey using the Protezione Civile
Regione Siciliana helicopter was promptly arranged. As a result, the initial effusive phases of the 2007 eruption could be reconstructed from the images recorded by the INGV-CT Web cameras as well as from thermal images collected during the helicopter surveys carried out during the afternoon of 27 February.

[16] Early on 22 February 2007, just before the onset of effusive activity, explosive activity was almost continuous at the NE and central craters (Figure 1d), with more than 20 events per hour (Figure 2). Images recorded by SPI at 1038 on 27 February showed an elongate thermal anomaly consistent with the development of a fracture that, after 1140, propagated gradually $\mathrm{NE}$ from vent $\mathrm{bN}_{2}$ toward vent $\mathrm{bN}_{1}$ (Figures $3 \mathrm{a}$ and $3 \mathrm{~b}$ ). This was accompanied by an increase in the intensity of explosive activity within the SW crater, with explosions reaching $\sim 200 \mathrm{~m}$ above the vents. The $\mathrm{bS}_{1}$ vent of the SW crater (Figure 1d) was a hornito-like structure producing jets of spatter, and vent $\mathrm{bS}_{2}$ (Figure 1d) fed ash-rich explosions without incandescent ejecta. Ash emissions from $\mathrm{bS}_{2}$ always followed explosions from the central and NE craters. At 1201 a small portion of the $\mathrm{bN}_{2}$ hornito collapsed (Figure 3b).

[17] After $\sim 1200$, explosions at vent $\mathrm{bN}_{1}$ were persistent and ballistics reached heights up to a few meters, resulting in fast accumulation of spatter around the vent. At 1223, SQT400 revealed a persistent hot spot on the NE rim of $b N_{1}$. This marked the continuation of fracture propagation between $b_{2}$ and $b N_{1}$, with the fracture system now extending to the outer rim of the crater terrace. At the same time, a second fracture opened within the NE crater, developing parallel to the previous fracture.

[18] By 1224, vent $\mathrm{bN}_{2}$ was emitting a small lava flow. This flow remained confined within the NE crater, ponding in the saddle between vent $\mathrm{bN}_{2}$ and vent $\mathrm{bN}_{1}$ (Figure 3c). At 1232, a second hot spot appeared on the NE crater rim 

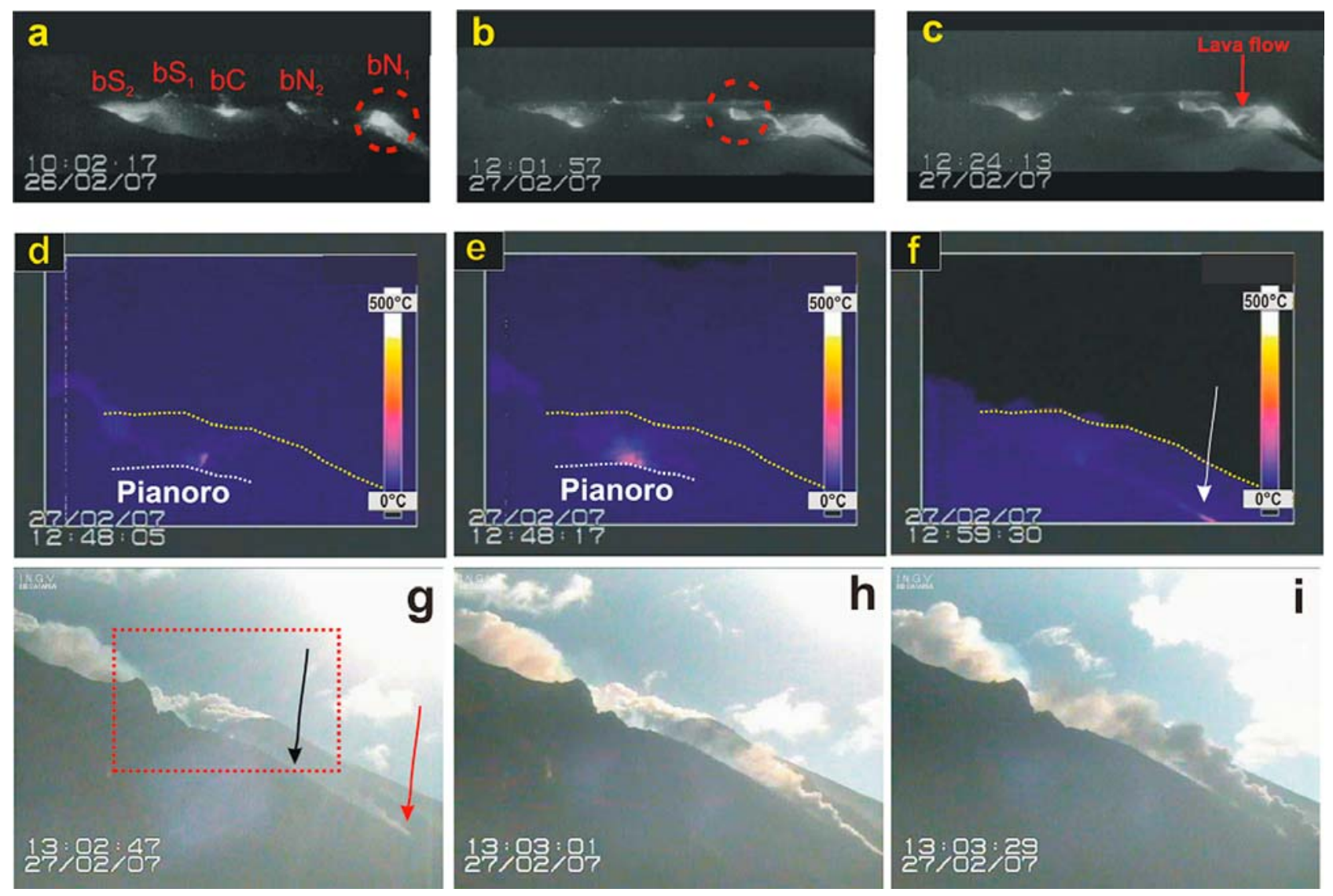

Figure 3. Images taken from $(\mathrm{a}-\mathrm{c})$ the SPI camera, $(\mathrm{d}-\mathrm{f})$ the SQT400 camera, and (g-i) the SQV400 camera (see Figure 1c for camera locations), showing the crater terrace and flow field during the opening phase of the 2007 effusive eruption. The chronological sequence of the images shown in Figures $3 \mathrm{~d}-3 \mathrm{i}$ tracks emplacement of lava flows fed by the fissure opening on the NE flank of the crater terrace. (a) Location and names of active vents as of 26 February 2007 (1 day before the start of the 2007 effusive eruption). Dashed red circle locates vent $\mathrm{bN}_{1}$, which collapsed the next day. (b) Image acquired during fissure propagation on 27 February 2007. Dashed red circle indicates the location of the upslope-propagating fissure, opening between $b_{2}$ and $b N_{1}$. Movement in this fissure caused, 1 min later, a small failure of the SE rim of vent $b N_{2}$. (c) Image showing lava flow extending across the saddle between vent $\mathrm{bN}_{1}$ and vent $\mathrm{bN}_{2}$. (d) Image obtained during the opening of vent 1 on the NE flank of the crater terrace. The dotted yellow line outlines the craters and the dotted white line traces the profile of Pianoro ( $650 \mathrm{~m}$ above sea level (asl)). (e) Image showing spreading of the first lava flow (FL1) across the 2002-2003 lava shield (dotted white line). (f) Image obtained after flow FL1 had begun to extend down the upper SDF itself. The white arrow indicates the position of the active lava flow front. (g) Image of FL1 spreading across the middle of the SDF. The location of the active flow front is marked by the red arrow (black arrow shows previous position, in Figure 3f; the distance between the two arrows is $\sim 150 \mathrm{~m}$ ). (h, i) Images acquired as the flow front extended onto the lower SDF, where it excavated the ground [Calvari et al., 2005a, 2005b], producing an increasingly thick ash cloud that obscured visibility, to finally enter the sea. The red square in Figure $3 \mathrm{~g}$ shows the area imaged in Figures 3d-3f.

marking the intersection of the second fracture with the outer rim of the crater terrace. Analysis of data recorded by the SPI camera allowed us to assess the direction of fracture development. The first and northernmost fissure within the $\mathrm{NE}$ crater propagated $\mathrm{NE}$ (i.e., from $\mathrm{bN}_{2}$ to $\mathrm{bN}_{1}$ ), whereas the southernmost fissure opened later and propagated SW (i. e., from $\mathrm{bN}_{1}$ to $\mathrm{bN}_{2}$ ). Between 1232 and 1243, both fractures propagated toward the NE, with propagation being accompanied by explosions and by gas/steam emission from the NE crater that eventually obscured visibility at the SPI.
[19] At 1248, SQT400 captured the opening of a vent (vent 1; Figures 1c and 3d) and the emplacement of a lava flow (Figure 3e) on the 2002-2003 lava shield (Pianoro) located on the upper SDF at $\sim 650 \mathrm{~m}$ asl. This fed the first lava flow (FL1; Figures 3e-3i, 4, and 5), which was emplaced northward down the SDF. By 1259, this had spread across the break-in slope at the top of the SDF (Figures $3 \mathrm{f}$ and $3 \mathrm{~g}$ ), and it reached the sea around 1303, when SQV400 showed a vapor cloud rising above the sea entry (Figures $3 \mathrm{~h}$ and 3i). This means that the flow traveled 


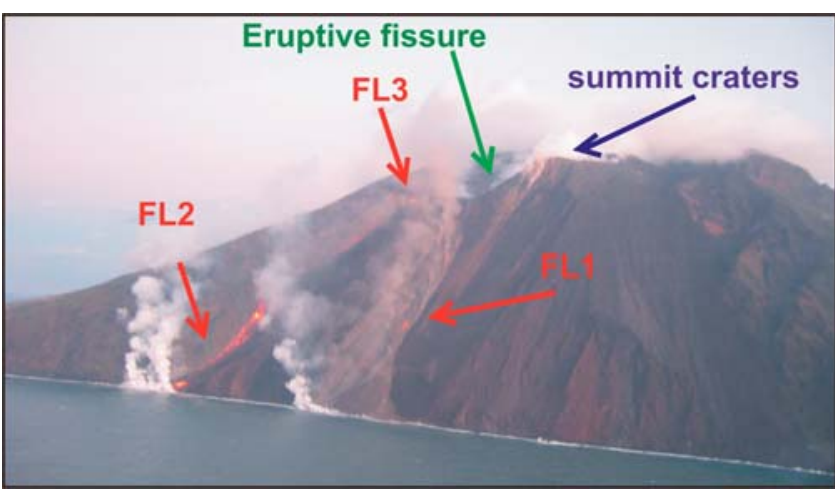

Figure 4. View from the western side of the SDF at 1630 on 27 February 2007, showing the first lava flows reaching the sea. Note the eruptive fissure on the NE flank of the crater terrace, releasing white steam and gas, and the white columns of steam rising from the lava flow fronts where they meet the sea. Brown dust rising around and above FL1 results from ground excavation and landslides triggered by lava flow advance. (Photo taken from the helicopter of Protezione Civile Regione Siciliana by S. Calvari.)

a distance of $1.2 \mathrm{~km}$ (the distance from the vent to the coast) in $15 \mathrm{~min}$, so that the mean speed of the flow front was $\sim 1.3 \mathrm{~m} \mathrm{~s}^{-1}$. This lava flow emplaced on the $>30^{\circ}$ steep SDF slope, and its velocity was comparable with the 28 December 2002 lava flow reported by Lodato et al. [2007]. Lava flow emplacement was accompanied by little landslides that were active on the SDF at any elevation below the summit craters (Figure 4). FL1 was fed until at least 1500 .

[20] Explosive activity at $\mathrm{bN}_{1}$ lasted until 1256, when activity at this vent died out. At 1305, the rapidly deposited spatter around $\mathrm{bN}_{1}$ collapsed to form a small landslide of hot debris, as revealed by SQT400. At 1248 and 1332, single bursts of hot gas were observed at the base of the eruptive fissure on the Pianoro and then along the NE fissure until 1325. After 1332, no more explosive activity occurred either at the summit craters or at the base of the eruptive fissure $(\sim 650 \mathrm{~m}$ asl).

[21] At 1457, a new lava flow (FL2; Figure 4) was erupted from the base of the NE fissure. This initially spread across the Pianoro. At 1501, this flow descended the steep slopes on the eastern margin of the SDF to reach the sea in just a few minutes, where it generated a second sea entry and associated vapor cloud. With the formation of FL2, supply to FL1 ceased and this flow began to cool.

[22] At 1535, a third lava flow (FL3) appeared in a central position between the two previous flows. This was probably an overflow from the main channel formed along FL2 (Figure 4). Evidence for this is the fact that FL3 had already stopped moving at 1544 . Channel overflows are usually short-lived [e.g., Bailey et al., 2006; Harris et al., 2009], so that the short life of this flow appears to support its origin as an overflow.

[23] After 1600, all three lava flows appeared to be supplied no longer and were cooling. Although incandescent blocks detaching from the margins still exposed the hot inner portions of the cooling flows (Figures 5a and 5b), a thermal helicopter survey at 1630 showed FL1 to be cooling and surrounded by landslides. At the same time, FL2 was only slowly moving, although the incandescent front of FL3 was visible between dust clouds, and two vapor columns were apparent where flows were entering the sea (Figure 4). Between 1600 and 1800, SQT400 showed glow, possibly due to weak explosive activity within the SW crater of the crater terrace. Between 1800 and 1836, a small and slow moving lava flow was emplaced over FL3 and FL2, but activity appeared to be waning.

\subsection{Effusion From the $\mathbf{4 0 0} \mathrm{m}$ Vent (Vent 2)}

[24] At 1825:59 on 27 February, a thick ash and vapor column was recorded by SQV400 (Figures 5a-5f). This heralded the opening of a new effusive vent on the SDF at the 400 m elevation (vent 2; Figure 1c). The opening of this vent was also recorded by SQT400, which imaged initial explosions from this site followed immediately by the formation of hot debris flows. As also occurred in 2002-2003 [Pioli et al., 2008], debris reached the sea within a few minutes, forming a dense vapor cloud that obscured visibility. At 1825:59, SQV400 recorded the first lava flow (FL4; Figures 5c-5e) erupting from this vent. This flow reached the sea within minutes. After 1900, vigorous, pulsing degassing started at vent 2 (Figure 1c). This become more vigorous with time. At 2034:02, SQT400 recorded a sudden gas explosion in the area of Pianoro.

[25] The apparent effusion rate from vent 2 , evaluated on the basis of the glow observed from SQV400, dropped on 28 February after 0138 . This was matched by a decline in the frequency of gas pulses from the same vent. Between 0400 and 0500 , vent 2 deepened by a few meters, so that it was no longer visible from SQV400, with this camera just showing the gas cloud released from the vent to be spreading southward.

[26] On 28 February, a helicopter-based thermal survey at $\sim 0830$ revealed a depression just above vent 2 and a number of degassing fractures on Pianoro, just at the base of the NE crater (Figures 6a and 6b). Vent 2 remained active until the final day of the eruption, 2 April, with lava emitted by vent 2 accumulating along the shore to modify the coastline significantly, forming a bench that extended seaward by several tens of meters. This bench was particularly prominent in early March.

\subsection{Collapses Within the Crater Terrace, 4-9 March}

[27] From 4 March, large blocks were seen falling from the crater rim to the crater floor. The onset of rockfall activity could have been earlier but could not be confirmed because of poor weather conditions, which hampered visual and thermal observations. By this time, a field of concentric, arcuate fractures had also opened around the craters. Rockfalls became more common in the following days, causing a significant widening of the crater rim and a thick accumulation of debris on the crater floor. At the same time, there was a visible widening of the concentric fractures surrounding the craters. Rockfalls were mostly concentrated around the NE crater. Images from the SPI showed how this rockfall activity modified the profile of the crater rim (Figures 7a-7c), especially at the NE sector (in the foreground of Figure 7c), whose rim became low enough to allow viewing inside the crater.

[28] A helicopter-based thermal survey on 7 March showed that the fractures were beginning to extend into the craters, 

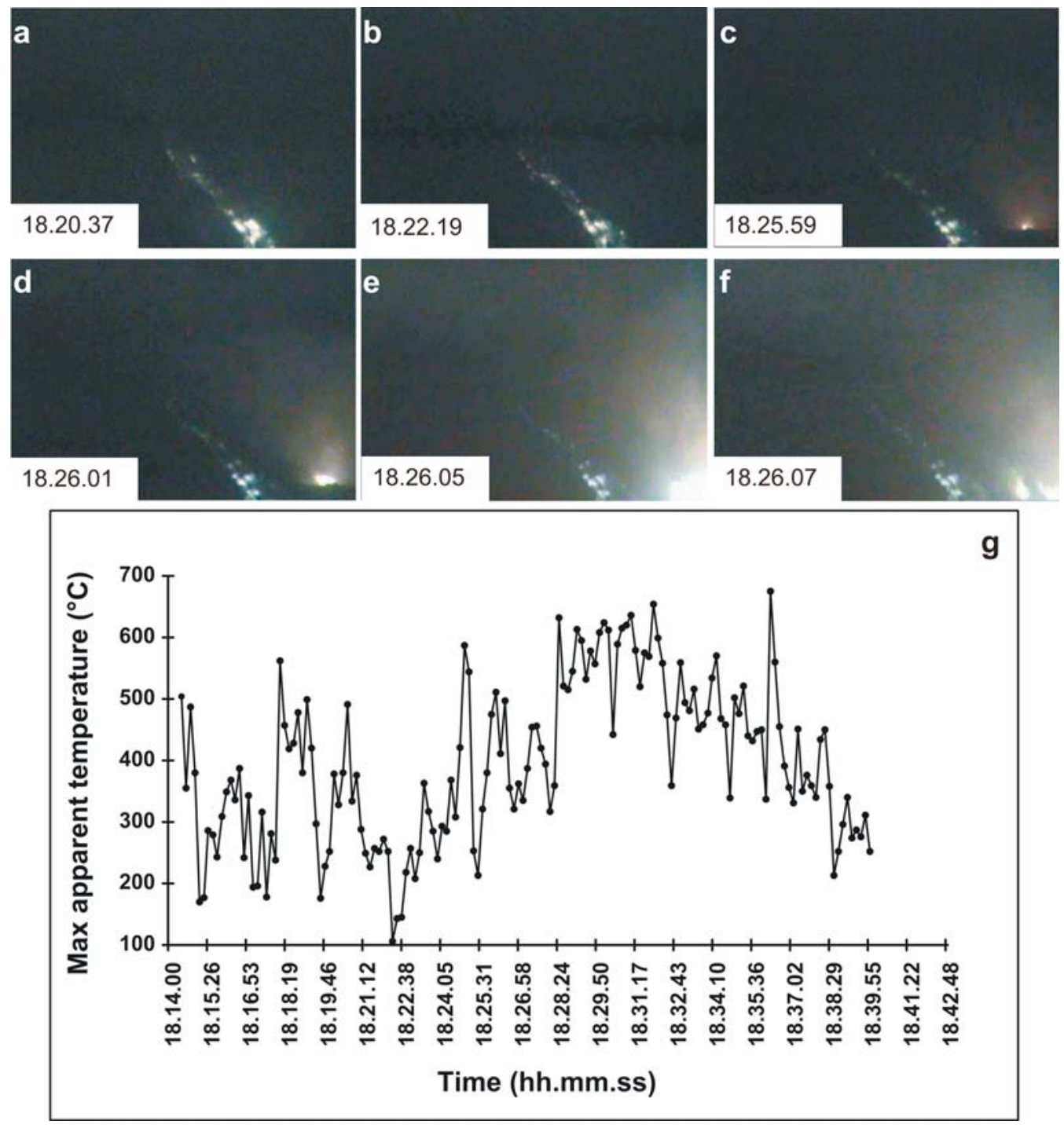

Figure 5. Sequence of frames recorded by camera SQV400 (see Figure 1c for location). (a, b) Images of lava flow activity. (c, f) Images charting the initial stages of the opening of vent 2 (see Figure $1 \mathrm{c}$ for location) on the afternoon of 27 February 2007. Images given in Figures $5 \mathrm{c}-5 \mathrm{f}$ also record the emission of FL4, debris flow, and associated dust clouds. (g) Graph showing the maximum apparent temperature recorded by camera SQT400, revealing variation due to the pulsing movement of the FL3 front, followed by an increase due to the opening of vent 2. Maximum temperature is sampled every $10 \mathrm{~s}$.

following the main (NE-SW) structural trend of the island. The fractures evolved rapidly during the next 2 days, when large blocks collapsed into the craters to form a thick pile of debris on the crater floor. The volume of material accumulated on the crater floor through collapses was estimated at $1-2 \times 10^{6} \mathrm{~m}^{3}$ [Neri and Lanzafame, 2009].

[29] Deep explosive activity from below the debris deposit continued to occur, with rockfalls within the craters often accompanied by ash emissions and gas-rich explosions from the vents still active below the debris carpet. No change was observed in the position of the vents within the crater terrace compared to the pre-eruptive distribution. The persistence of explosive activity at the crater terrace suggested that magma was still present at a shallow depth below the debris carpet and that the debris was not causing complete obstruction of the vents. Collapses continued even after the end of the effusive eruption, persisting at least until the end of June 2007.

\subsection{Shutdown of Vent 2, Development of the $550 \mathrm{~m}$ Elevation Vent (Vent 3), and Reactivation of Vent 2}

[30] Between 7 and 8 March, the output rate from vent 2 decreased, with effusion from this vent completely shutting down on the afternoon of 8 March. On 9 March, a new vent (vent 3; Figures 1c and 8a) opened at $550 \mathrm{~m}$ asl on the northern flank of the NE crater, in the same position as the $550 \mathrm{~m}$ elevation vent of the 2002-2003 eruption as mapped by Calvari et al. [2005a, 2005b].

[31] A few minutes before 1500 on 9 March, the Guardia di Finanza Guides reported rockfalls, landslides, and gas emissions coming from the middle of the SDF, where vent 3 soon 


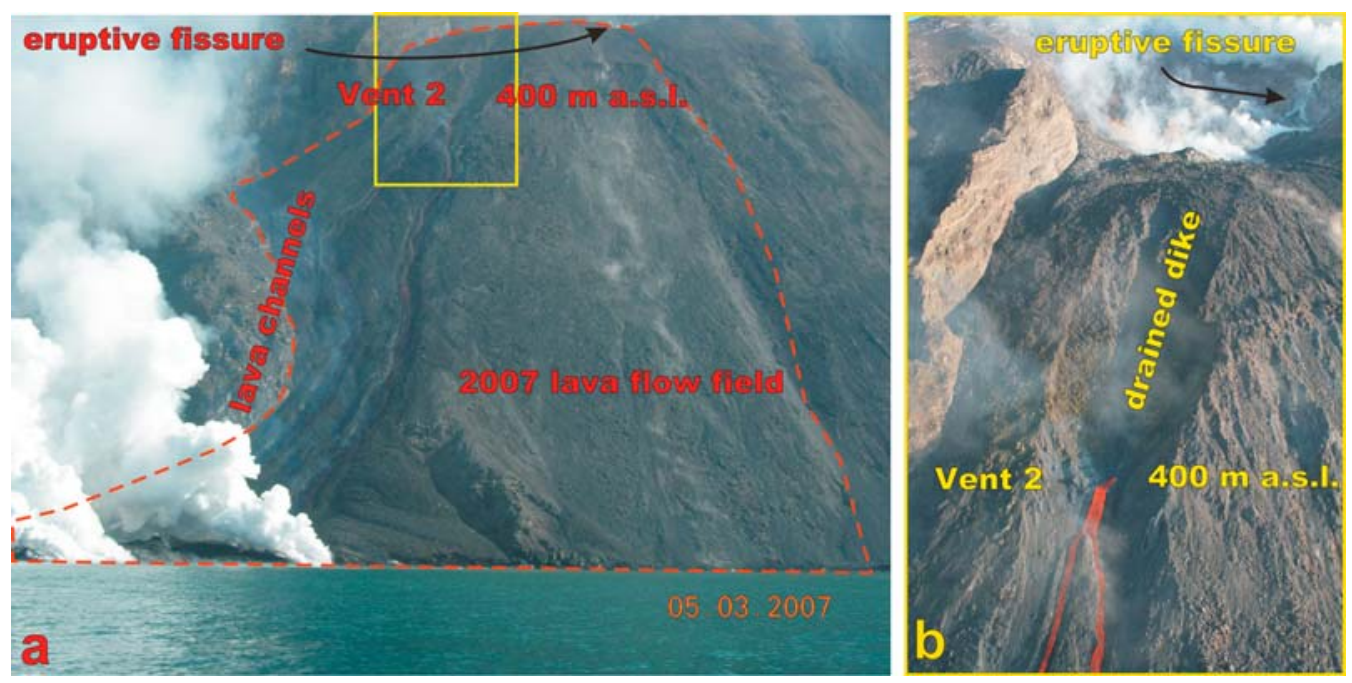

Figure 6. (a) Photo of the SDF taken from the NNE during a boat-based survey performed on 5 March 2007 showing vent 2 and its lava flow field (outlined by the dotted red line). The flow has reached the sea, to generate thick steam clouds. The yellow box denotes the area imaged in Figure $6 \mathrm{~b}$. (b) Photo of the SDF taken from the NE during a helicopter survey on 4 March 2007 showing vent 2 on the eastern SDF and the depression above the vent region caused by dike drainage. The line of fume apparent at the upper right marks the eruptive fissure on the NE flank of the crater terrace. The steaming white area below this marks the location of lava flows erupted during the opening phase. (Photo is courtesy of the Dipartimento di Protezione Civile.)

opened to immediately feed lava flow. Analysis of the thermal images recorded by SQT400 allowed us to plot maximum apparent temperature against time for the lower portion of the SDF (Figure 8b). Although the area covered by the camera did not include the location of vent 3 , which was behind the 2002-2003 lava flow field, Figure 8b shows a sudden increase in maximum apparent temperature at 1331:55, with values of $\sim 300^{\circ} \mathrm{C}$. We attribute this increase to the presence of lava fed from vent 3 . Lava reached the sea at 1743 , giving rise to a thick vapor cloud. Vent 3 remained active for less than $24 \mathrm{~h}$.

[32] While vent 3 was closing down, effusive activity at vent 2 renewed. Vent 2 remained active until 2 April, when the eruption ceased in the early afternoon. Vent 3 produced just a narrow lava flow in the middle of the SDF (Figures 1c and 8a). This lava flow soon disintegrated, so that it was no longer visible just a few days after its emplacement. Such crumbling behavior and volume loss are typical of lava flows emplaced on Stromboli's steep slopes [Lodato et al., 2007]. The steep topography and the loose, fine-grained material that made up the surface at this location accelerated the disintegration of the flow. The location of the flow was also rapidly covered by debris tumbling from sources located higher on the SDF, as observed during the 2002-2003 eruption [Calvari et al., 2005a, 2005b].

\subsection{The Paroxysm of 15 March}

[33] On 15 March, while lava output from vent 2 was still ongoing, a major, paroxysmal explosion from the crater terrace occurred at 2038:16. The explosion was recorded by the three INGV-CT Web cameras installed on the upper part of the volcano; each offered different views and details of the event (Figure 9). The SPI camera gave a good overall view of the vents within the crater terrace at a frame rate of $2 \mathrm{~s}$
(Figures 9a-9d), but being $\sim 250 \mathrm{~m}$ away from the vents, it was soon destroyed by fallout from the eruption cloud. However, it showed that the explosion started with smallvolume collapses from the inner crater rim and emission of a dilute ash cloud (Figure 9a). Two seconds later, a dense, hot cloud of bombs, lapilli, and lithics was erupted from the NE crater (Figure 9b), at a muzzle velocity of $\sim 100 \mathrm{~m} \mathrm{~s}^{-1}$ [Andronico et al., 2007]. This opening sequence of events was very similar to that recorded at the onset of the 5 April 2003 paroxysm at Stromboli [Calvari et al., 2006; Harris et al., 2008]. The explosion then propagated across the crater terrace to also involve the SW crater (Figures 9c and 9d).

[34] The paroxysm, observed from SQT400 (Figures 9e9h), showed two clouds produced by the two crater regions (north and south; Figure 9f). These two clouds spread in opposite directions (Figures $9 \mathrm{f}$ and $9 \mathrm{~g}$ ), reaching heights of well over $500 \mathrm{~m}$ above the craters (Figures $9 \mathrm{~g}$ and $9 \mathrm{~h}$ ); that is, they extended beyond the FOV of our camera, which covered a zone $500 \mathrm{~m}$ above the craters. A maximum height of 3000 $3500 \mathrm{~m}$ asl was estimated from satellite images [Spinetti et al., 2007, Rapporto eruzione Stromboli 9-16 marzo 2007; http:// www.ct.ingv.it/Report/BollettinoCNT_160307_Stromboli\% 20(2).pdf], which translates to $\sim 225 \overline{0}-2750 \overline{\mathrm{m}}$ above the craters. The SQT400 camera also showed four other similarities to the 5 April 2003 paroxysm as described by Calvari et al. [2006], Rosi et al. [2006], and Harris et al. [2008].

[35] 1. The eruption was characterized by multiple explosions from the three summit crater zones, packaged into three distinctive events (Figure 9h), as revealed by peaks in the maximum apparent temperature record derived from SQT400 thermal images (Figure 9i).

[36] 2. Column collapse fed pyroclastic flows extending up to Bastimento (Figure 9h). 

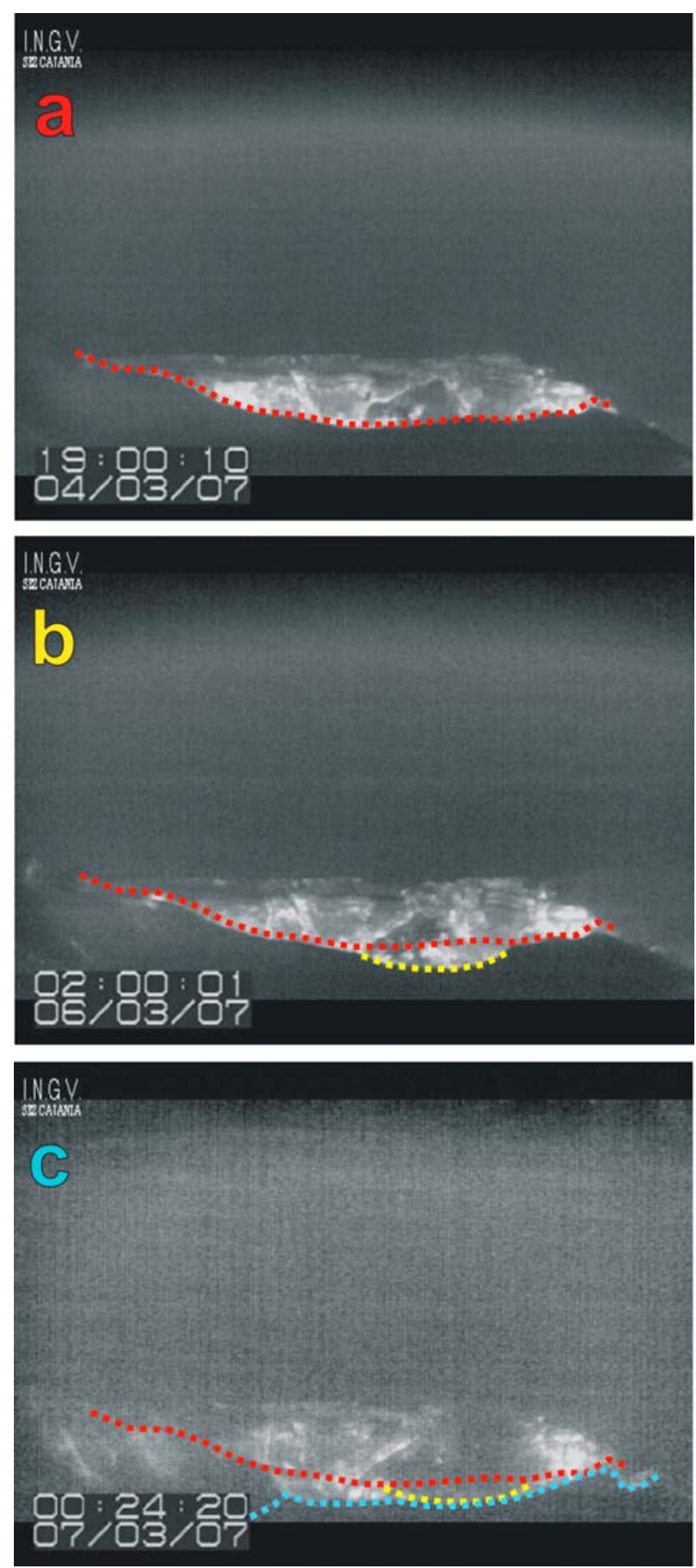

Figure 7. Sequence of images of the crater terrace recorded by the SPI camera between 4 and 7 March 2007, showing widening of the crater rim by repeated collapses. The dotted colored lines indicate changes in the position of the crater rim. The increasing darkness and decreasing quality of the images are the result of ash emission during collapses.

[37] 3. The paroxysm continued for $\sim 7 \mathrm{~min}$, with fire fountaining shifting to the $\mathrm{SW}$ crater region as the event developed and becoming less intense, with the number and intensity of events gradually decreasing.
[38] 4. The paroxysm erupted lithic blocks and juvenile material that reached a lowest elevation of $300 \mathrm{~m}$ asl. Several hot blocks triggered vegetation fires, and a shower of ash and lapilli covered the villages of Ginostra and Stromboli.

[39] The paroxysm caused a further widening of the crater terrace, with a large portion of the southern rim being removed by the explosion.

\subsection{Lava Flow Activity After 15 March}

[40] After the 15 March paroxysm, a general decreasing trend was observed in the lava flow output from vent 2 , until 20 March. This decrease was reflected by lava flow bifurcation and the development of many active lobes that often did not reach the sea, as observed during periods of decreased output at the 2002-2003 flow field [Calvari et al., 2005a, 2005b; Lodato et al., 2007]. On $20 \mathrm{March}$, an apparent increase in output was recorded by SQT190, which showed a second lava flow extending down the SDF. An increase in output was also suggested by the fact that the lava flows also began to lengthen, to again reach the sea. A further decrease in output in the following days was reflected in the formation of lava tubes in the upper part of the lava flow field and in the piling-up of flows above the lava delta that had formed at the coast. Lava tubes progressively extended between 20 and $24 \mathrm{March}$, with the continued decrease in output from vent 2 causing the lava flow fronts to halt at progressively higher elevations. On $31 \mathrm{March}$, an increase in output from vent 2 again caused the flow fronts to reach the sea, triggering the formation of thick steam columns. This increase lasted only a few hours, so that by the afternoon of 31 March there was a new regression, with flow fronts stopping short of the sea. Output decreased again over the following days, with the effusive eruption completely stopping between $\sim 0900$ and $\sim 1600$ on 2 April. In fact, three small flows were still active during the helicopter survey carried out at 0900, whereas just vent incandescence was observed during the next survey, carried out at 1600 .

\section{Effusion Rates From Thermal Data}

[41] Effusion rates estimated from helicopter- and satellitecollected data during Stromboli's 2007 were, generally, in good agreement (Table 1 and Figure 10), with errors typically being $\pm 40 \%$, a value that is comparable to errors affecting field-based measurements [e.g., Harris and Neri, 2002; Calvari et al., 2003, 2005a, 2005b; Lautze et al., 2004; Bailey et al., 2006; Harris et al., 2007]. On 4 March, we were able to apply a different approach to extract effusion rates and crosscheck the thermal-data-derived values. On this day, we could estimate channel dimensions and, by taking images collected at known times and tracking blocks moving on the channel surface, estimate a flow surface velocity of $1.7 \mathrm{~m} \mathrm{~s}^{-1}$. Hence, using a velocity value that was two-thirds of the surface velocity (as suggested by Calvari et al. [2003]), and considering a channel width of $3 \mathrm{~m}$ and a depth of $1 \mathrm{~m}$, we obtained an effusion rate of $\sim 3 \mathrm{~m}^{3} \mathrm{~s}^{-1}$. This was consistent with both satellite- and FLIR-derived values for the same day (Figure 10a). Multiple helicopter-based measurements performed on the same day also allowed us to track small fluctuations in effusion rate and check the repeatability of our measurements. On 26 March, for example, we carried out measurements at three times: 0700, 1045, and 1400. These 

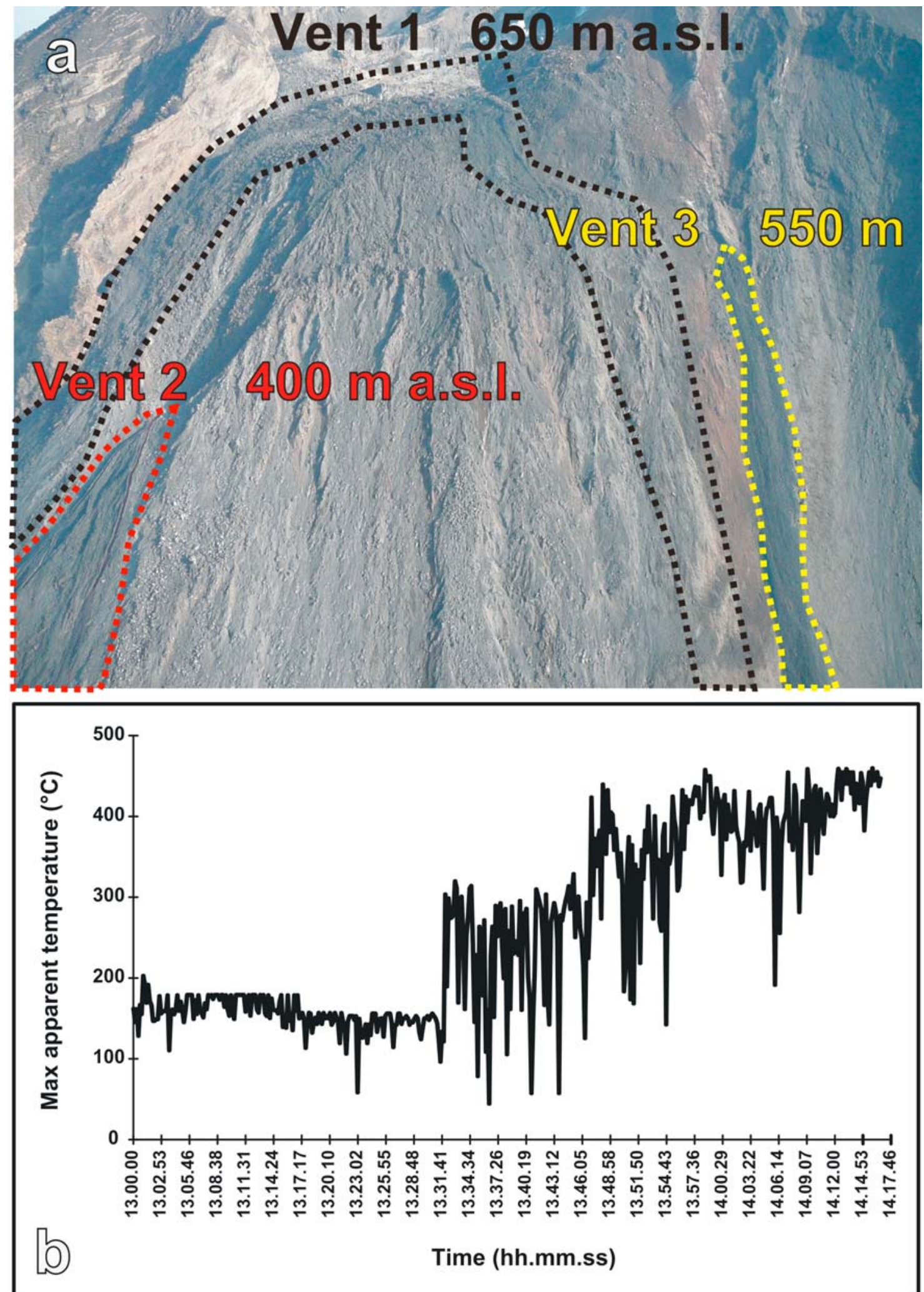

Figure 8. (a) Photo of the SDF taken from the NW showing the position of vents 1,2, and 3, as well as the flow fields that they fed: vent 1 flow field, dotted black outline; vent 2 flow field, dotted red outline; vent 3 flow field, dotted yellow outline. Note the deep elongated depressions above vents 2 and 3 due to dike drainage. (b) Graph of maximum apparent temperature recorded by the SQT400 camera during 9 March (sampling rate, $10 \mathrm{~s}$ ). The increase in temperature at 1331:49 relates to the opening of vent 3 at $550 \mathrm{~m}$ asl. 

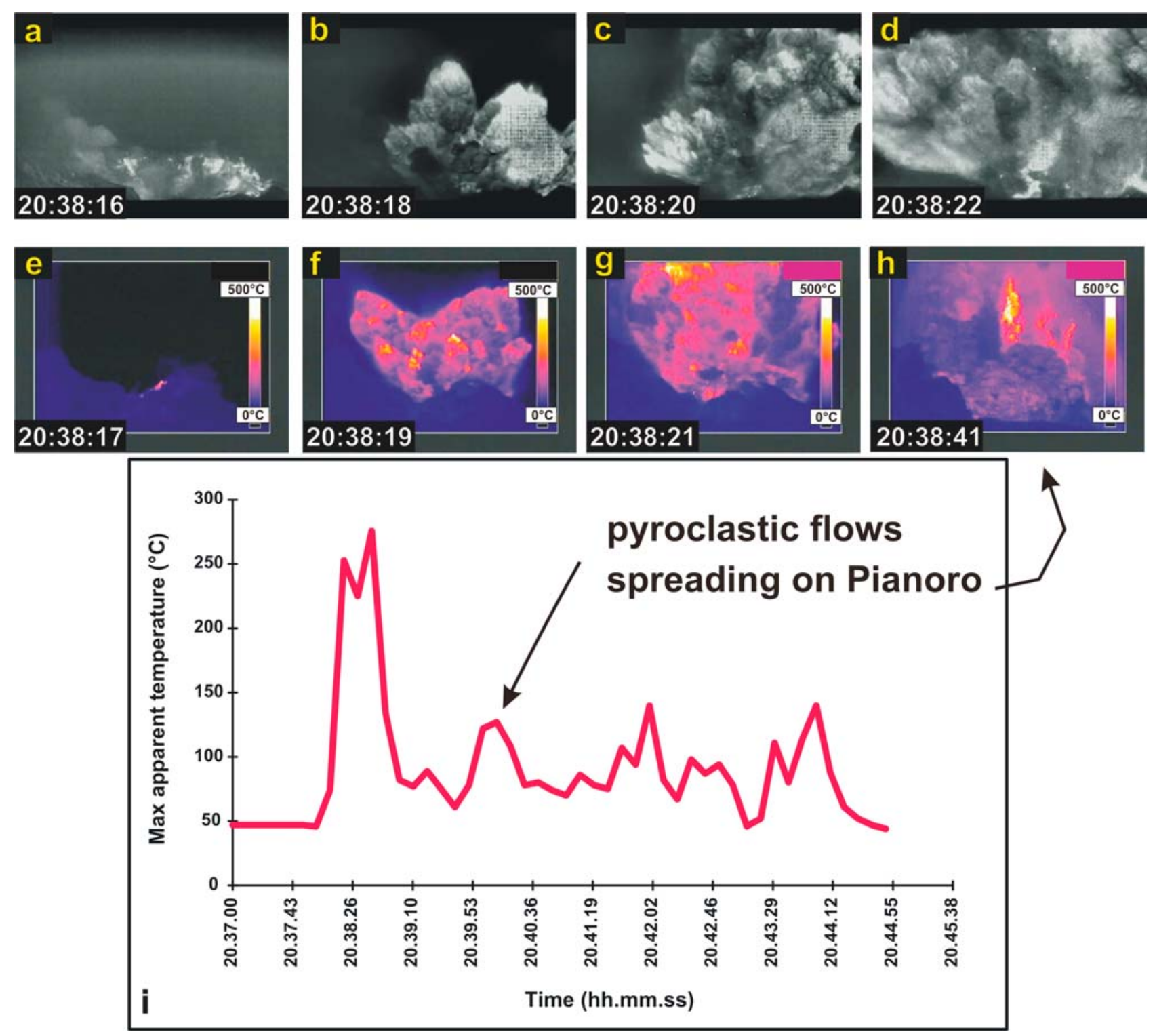

Figure 9. Sequence of images recorded by the SPI camera during the 15 March 2007 paroxysm. (a) Image recording pre-explosion collapses from the inner crater walls. (b) Image recording the initial phase of the paroxysm at the NE crater at 2038:18. (c) Image acquired at 2038:20 showing explosion source propagation to the central crater. (d) Image acquired at 2038:22 showing propagation to the SW crater. (e, h) The same sequence of events recorded from the SQT400 camera. From this camera we see the craters from below and from the NE. The first image in the series (Figure 9e) shows that just a small thermal anomaly was visible from below at the onset of the paroxysm. The second image (Figure 9f) shows that when the paroxysm began, two diverging eruptive clouds formed and extended out of the top of the camera field of view. The image in Figure 9h shows three fire fountains from each of the three crater zones and pyroclastic flows spreading up to Bastimento (pointed out by black arrows.) (i): Graph of the maximum apparent temperature recorded on 15 March 2007 by the SQT400 camera, showing the sudden start of the 15 March paroxysm and several peaks caused by fire fountain activity and pyroclastic flows. The thermal signal caused by pyroclastic flows spreading on the Pianoro is highlighted by the arrow.

thermal camera data yielded effusion rates of $0.7 \pm 0.4,0.8 \pm$ 0.5 , and $0.9 \pm 0.5 \mathrm{~m}^{3} \mathrm{~s}^{-1}$, respectively.

\subsection{Effusion Rate Chronology From the Thermal Image Time Series}

[42] The 2007 eruption was first evident as a major thermal anomaly in AVHRR imagery acquired at 2006 on 27
February 2007. About an hour later, at 2100, the first eruption-related thermal anomaly was detected by MODIS. Throughout the effusive event, a total of 219 AVHRR and 118 MODIS images were acquired. Of these, 20 AVHRR and 18 MODIS images had sufficient quality to allow hot spot analysis and conversion to effusion rate. Within the data set, four periods (spanning 28 February-4 March, 6-11 March, 
Table 1. Effusion Rate Data From Advanced Very High Resolution Radiometer (AVHRR) and Moderate Resolution Imaging Spectroradiometer (MODIS) Satellite Data and From Forward Looking Infrared (FLIR) Helicopter Surveys

\begin{tabular}{|c|c|c|c|c|c|c|c|c|c|c|}
\hline \multirow[b]{2}{*}{ Date $(\mathrm{dd} / \mathrm{mm})$} & \multirow[b]{2}{*}{ Time UTC } & \multicolumn{3}{|c|}{$\operatorname{AVHRR}\left(\mathrm{m}^{3} \mathrm{~s}^{-1}\right)$} & \multicolumn{3}{|c|}{$\operatorname{MODIS}\left(\mathrm{m}^{3} \mathrm{~s}^{-1}\right)$} & \multicolumn{3}{|c|}{ FLIR $\left(\mathrm{m}^{3} \mathrm{~s}^{-1}\right)$} \\
\hline & & Minimum & Maximum & Mean & Minimum & Maximum & Mean & Minimum & Maximum & Mean \\
\hline $27 / 02$ & 1630 & & & & & & & 5.52 & 17.07 & $11.30 \pm 5.78$ \\
\hline $27 / 02$ & 2006 & 7.8 & 19.3 & $13.55 \pm 5.75$ & & & & & & \\
\hline $27 / 02$ & 2100 & & & & 3.65 & 17.28 & $10.46 \pm 6.8$ & & & \\
\hline $28 / 02$ & 0115 & & & & 3.68 & 17.43 & $10.55 \pm 6.8$ & & & \\
\hline $28 / 02$ & 0830 & & & & & & & 3.69 & 8.66 & $6.18 \pm 2.49$ \\
\hline $02 / 03$ & 0800 & & & & & & & 1.46 & 5.15 & $3.31 \pm 1.85$ \\
\hline $04 / 03$ & 1015 & & & & 0.75 & 3.56 & $2.1 \pm 1.04$ & 1.49 & 4.61 & $3.05 \pm 1.56$ \\
\hline $04 / 03$ & 2131 & 1.1 & 2.8 & $1.65 \pm 0.85$ & & & & & & \\
\hline $05 / 03$ & 0101 & 1.3 & 3.2 & $2.25 \pm 0.95$ & & & & & & \\
\hline $05 / 03$ & 0800 & & & & & & & 0.60 & 2.06 & $1.33 \pm 0.73$ \\
\hline $06 / 03$ & 0040 & & & & 0.4 & 1.91 & $1.15 \pm 0.75$ & & & \\
\hline $06 / 03$ & 0941 & 1.7 & 4 & $2.85 \pm 1.15$ & & & & & & \\
\hline $06 / 03$ & 1000 & & & & & & & 0.50 & 2.00 & $1.25 \pm 0.75$ \\
\hline $06 / 03$ & 1226 & 1.1 & 2.7 & $1.9 \pm 0.8$ & & & & & & \\
\hline $07 / 03$ & 1130 & & & & & & & 0.45 & 1.73 & $1.09 \pm 0.64$ \\
\hline $08 / 03$ & 0800 & & & & & & & 0.70 & 2.40 & $1.55 \pm 0.85$ \\
\hline $09 / 03$ & 0830 & & & & & & & 0.33 & 1.48 & $0.91 \pm 0.58$ \\
\hline $10 / 03$ & 0830 & & & & & & & 0.32 & 1.65 & $0.99 \pm 0.67$ \\
\hline $11 / 03$ & 0055 & & & & 1.12 & 5.31 & $3.21 \pm 2.1$ & & & \\
\hline $11 / 03$ & 0830 & & & & & & & 0.73 & 2.50 & $1.6 \pm 0.89$ \\
\hline $11 / 03$ & 2029 & 0.6 & 1.6 & $1.1 \pm 0.5$ & & & & & & \\
\hline $11 / 03$ & 2125 & & & & 0.5 & 1.95 & $1.2 \pm 0.7$ & & & \\
\hline $12 / 03$ & 0125 & & & & 0.2 & 0.94 & & & & \\
\hline $12 / 03$ & 0900 & & & & & & & 0.16 & 0.85 & $0.51 \pm 0.35$ \\
\hline $12 / 03$ & 2020 & & & & 0.11 & 0.52 & $0.31 \pm 0.2$ & & & \\
\hline $13 / 03$ & 0030 & & & & 0.16 & 0.77 & $0.46 \pm 0.3$ & & & \\
\hline $13 / 03$ & 0900 & & & & & & & 0.17 & 0.86 & $0.52 \pm 0.35$ \\
\hline $13 / 03$ & 1255 & 1.4 & 3.3 & $2.35 \pm 0.95$ & & & & & & \\
\hline $13 / 03$ & 2100 & & & & 0.98 & 4.66 & $2.82 \pm 1.8$ & & & \\
\hline $14 / 03$ & 0115 & & & & 0.89 & 4.24 & $2.5 \pm 1.6$ & & & \\
\hline $14 / 03$ & 0900 & & & & & & & 0.47 & 1.61 & $1.04 \pm 0.57$ \\
\hline $14 / 03$ & 2100 & 0.5 & 1.1 & $0.8 \pm 0.3$ & & & & & & \\
\hline $15 / 03$ & 1200 & & & & & & & 0.19 & 0.95 & $0.57 \pm 0.38$ \\
\hline $15 / 03$ & 2027 & 0.4 & 0.9 & $0.65 \pm 0.25$ & & & & & & \\
\hline $16 / 03$ & 0730 & & & & & & & 0.30 & 1.50 & $0.90 \pm 0.60$ \\
\hline $16 / 03$ & 1025 & 0.8 & 1.9 & $1.35 \pm 0.55$ & & & & & & \\
\hline $16 / 03$ & 1224 & 2.1 & 5 & $3.55 \pm 1.45$ & & & & & & \\
\hline $16 / 03$ & 2014 & 0.9 & 2.1 & $1.5 \pm 0.6$ & & & & & & \\
\hline $17 / 03$ & 0037 & 0.4 & 1 & $0.7 \pm 0.3$ & & & & & & \\
\hline $17 / 03$ & 1030 & & & & & & & 0.22 & 1.11 & $0.67 \pm 0.45$ \\
\hline $25 / 03$ & 0730 & & & & & & & 0.28 & 1.10 & $0.69 \pm 0.41$ \\
\hline $26 / 03$ & 0700 & & & & & & & 0.28 & 1.16 & $0.72 \pm 0.44$ \\
\hline $26 / 03$ & 0954 & 0.6 & 1.4 & $1 \pm 0.4$ & & & & & & \\
\hline $26 / 03$ & 1045 & & & & & & & 0.32 & 1.34 & $0.83 \pm 0.51$ \\
\hline $26 / 03$ & 1221 & 0.7 & 1.6 & $1.15 \pm 0.25$ & & & & & & \\
\hline $26 / 03$ & 1400 & & & & & & & 0.34 & 1.38 & $0.86 \pm 0.52$ \\
\hline $26 / 03$ & 2123 & 0.4 & 1 & $0.7 \pm 0.3$ & & & & & & \\
\hline $27 / 03$ & 2100 & 0.7 & 1.7 & $1.2 \pm 0.5$ & & & & & & \\
\hline $27 / 03$ & 2125 & & & & 0.95 & 4.48 & $2.75 \pm 1.76$ & & & \\
\hline $28 / 03$ & 0030 & & & & 0.18 & 0.84 & $0.51 \pm 0.33$ & & & \\
\hline $28 / 03$ & 0045 & & & & 0.44 & 2.07 & $1.25 \pm 0.8$ & & & \\
\hline $28 / 03$ & 1201 & 0.7 & 1.6 & $1.15 \pm 0.45$ & & & & & & \\
\hline $28 / 03$ & 2037 & 0.5 & 1.4 & & & & & & & \\
\hline $29 / 03$ & 0045 & & & & 0.63 & 2.99 & $1.81 \pm 1.18$ & & & \\
\hline $30 / 03$ & 1400 & & & & & & & & & \\
\hline $31 / 03$ & 2100 & & & & 0.63 & 2.99 & $1.81 \pm 1.20$ & & & \\
\hline $31 / 03$ & 2108 & 0.5 & 1.3 & $0.9 \pm 0.4$ & & & & & & \\
\hline $01 / 04$ & 0115 & & & & 0.5 & 2.36 & $1.43 \pm 0.93$ & & & \\
\hline $01 / 04$ & 0124 & 0.4 & 0.9 & $0.65 \pm 0.25$ & & & & & & \\
\hline $01 / 04$ & 1250 & 0.6 & 1.3 & $0.95 \pm 0.35$ & & & & & & \\
\hline $01 / 04$ & 2045 & 0.9 & 2.2 & $1.55 \pm 0.65$ & & & & & & \\
\hline
\end{tabular}

18-25 March, and 2-11 April) suffered prolonged cloud cover, so that no images of suitable quality for analysis were available during these periods.

[43] Effusion rates obtained from the FLIR, AVHRR, and MODIS data are given in Figure 10a and Table 1. Data derived from the three data sets show identical trends, with values peaking between 17 and $19 \mathrm{~m}^{3} \mathrm{~s}^{-1}$ during 27 28 February (Figure 10a). This peak was followed by a decline to 1 to $4 \mathrm{~m}^{3} \mathrm{~s}^{-1}$ by $4 \mathrm{March}$. Effusion rates remained at similar low levels throughout the remainder of the eruption, 

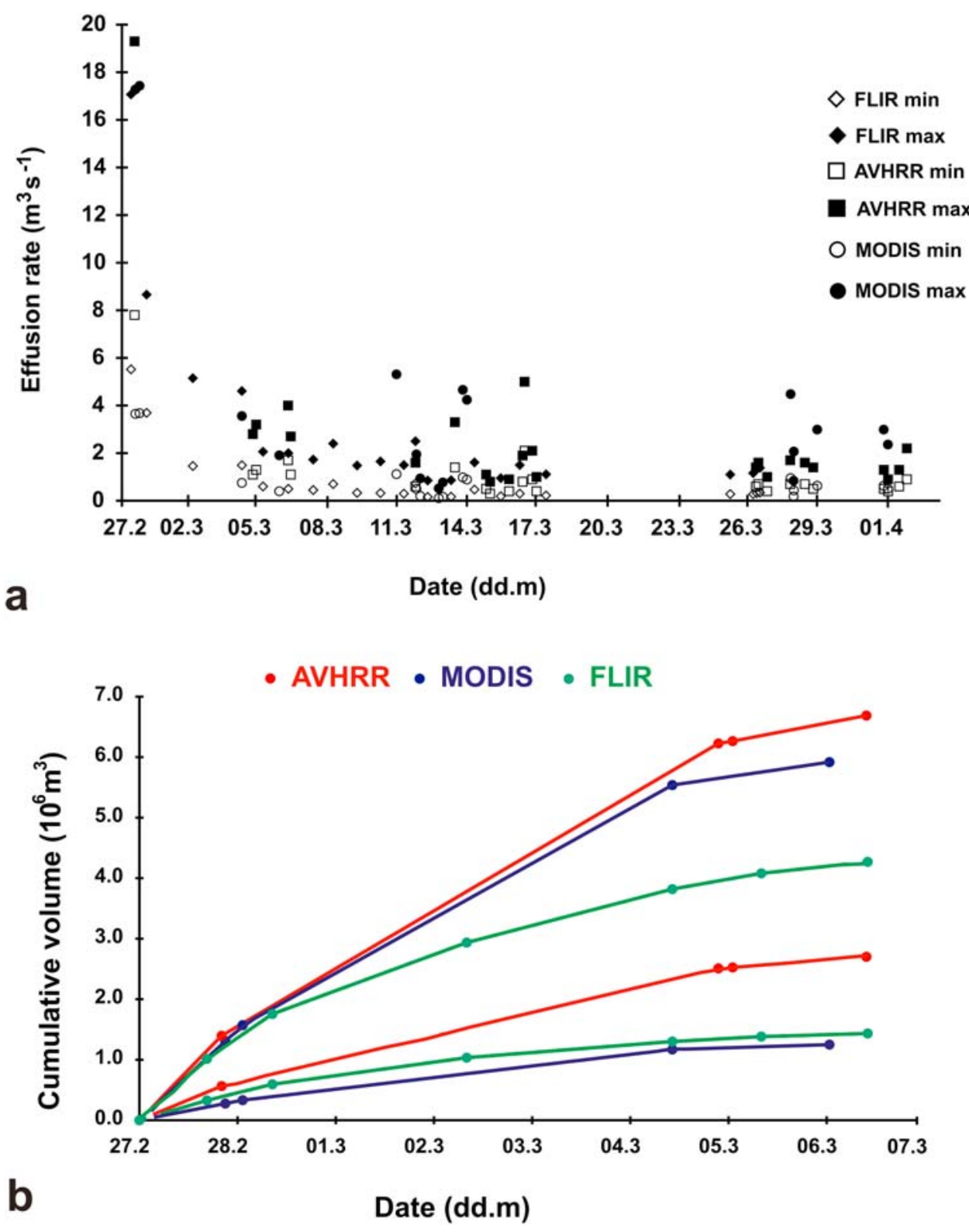

Figure 10. (a) Graph plotting effusion rates obtained from thermal camera, Advanced Very High Resolution Radiometer, and Moderate Resolution Imaging Spectroradiometer data, showing high initial values followed by a roughly steady trend punctuated by small pulses. (b) Graph of the maximum and minimum cumulative volumes calculated from data in Figure 10a.

with mean values and standard deviations during the cloudfree periods of $2.0 \pm 1.2 \mathrm{~m}^{3} \mathrm{~s}^{-1}$ (4-6 March; 6 images), $1.4 \pm$ $1.4 \mathrm{~m}^{3} \mathrm{~s}^{-1}$ (11-17 March; 17 images), $1.2 \pm 1.0 \mathrm{~m}^{3} \mathrm{~s}^{-1}$ (2629 March; 10 images), and $1.2 \pm 0.9 \mathrm{~m}^{3} \mathrm{~s}^{-1}$ (31 March-1 April; 6 images). Thus, except for the short effusion rate peak at the onset of the eruption, activity was characterized by a dominant phase of low effusion rates. However, as observed during previous effusive eruptions at Stromboli [Harris et al., 2005b; Lodato et al., 2007] and Etna [Lautze et al., 2004; Harris et al., 2005a; Bailey et al., 2006; James et al., 2007], even apparently steady, low-effusion-rate eruptions undergo variations over time scales of minutes to hours. During the 2007 eruption, for example, the generally steady effusion rate trend recorded between 11 and 17 March showed variations ranging between 5.0 and $0.2 \mathrm{~m}^{3} \mathrm{~s}^{-1}$ (Figure 10a) and displayed three effusion rate cycles. Each cycle was characterized by a relatively high-effusion-rate phase followed by a low-effusion-rate phase. The first cycle began with a maximum of $5.3 \mathrm{~m}^{3} \mathrm{~s}^{-1}$, as recorded on $11 \mathrm{March}$. This was followed by a decrease to $0.5 \mathrm{~m}^{3} \mathrm{~s}^{-1}$ by 12 March (Table 1). The onset of the second cycle was marked by a recovery to $4.7 \mathrm{~m}^{3}$ $\mathrm{s}^{-1}$ by 2100 on 13 March. Effusion rates declined again, to $0.6 \mathrm{~m}^{3} \mathrm{~s}^{-1}$, by 0058 on $15 \mathrm{March}$. The last cycle began with an increase to $5.0 \mathrm{~m}^{3} \mathrm{~s}^{-1}$ (observed at 1224 on $16 \mathrm{March}$ ), followed by a final decrease. Such lava effusion rate cycles were also observed during the 2002-2003 effusive eruption at Stromboli by Harris et al. [2005b] and were ascribed to recovery of the magma level in the central column during 
low-effusion-rate periods. Such recovery will increase the hydrostatic head in the conduit. An increase in the hydrostatic head then results in an increase in the effusion rate from the dike tapping the conduit at a lower level, which then results in drainage of the shallow system so that the cycle begins anew.

[44] Integration of effusion rates over time yielded cumulative volumes (Figure 10b; see also Table 2) and gave a final erupted volume of between $3.2 \times 10^{6}$ and $11 \times 10^{6} \mathrm{~m}^{3}$. The mean volume of $7.1 \times 10^{6} \mathrm{~m}^{3}$, when erupted over 34 days, gives a mean output rate of $2.4 \mathrm{~m}^{3} \mathrm{~s}^{-1}$. This is an order of magnitude higher than the mean output rates calculated during Stromboli's 2002-2003 eruption $\left(0.32 \pm 0.28 \mathrm{~m}^{3} \mathrm{~s}^{-1}\right.$ [Lodato et al., 2007]) and 1985-1986 eruption (0.34 \pm $0.05 \mathrm{~m}^{3} \mathrm{~s}^{-1}$ [Harris et al., 2000]). The cumulative volume plot in Figure 10b reveals the decline in effusion rate after the first 5.5 days from an inflexion between 28 February and $4 \mathrm{March}$. As a result, we move from a period of a high rate of volumetric increase $\left(6.6 \times 10^{5} \mathrm{~m}^{3} \mathrm{~d}^{-1}\right)$ during the first 5.5 days of the eruption to a low rate of increase $\left(1.2 \times 10^{5} \mathrm{~m}^{3}\right.$ $\mathrm{d}^{-1}$ ) thereafter. This means that $51 \%$ of the total volume was erupted over the first 5.5 days, or $16 \%$ of the eruption by time.

\section{Discussion}

[45] As observed prior to the 2002-2003 eruption [Calvari et al., 2005a, 2005b; Burton et al., 2008], explosive activity at the crater terrace increased to relatively high levels prior to the onset of Stromboli's 2007 effusive eruption. Calvari et al. [2005a, 2005b], Burton et al. [2008], and Ripepe et al. [2009] have argued that the number of explosions per hour is an indirect measure of magma input rate and magma level within the conduit, where an increasing magma level can be associated with more violent and frequent explosive activity. Hence, we interpret the increase in the number of explosions per hour prior to the 2007 effusive eruption as being the result of an increase in the level of the magma free surface within the conduit. This is consistent with other geophysical (seismic and infrasonic) data showing the explosion rate, pressure, and tremor to increase after January 2007 [Giudicepietro et al., 2009; Ripepe et al., 2009]. This increase was interpreted by Ripepe et al. [2009] as evidence for an increased magma supply to the shallow system. The main phases of the 2007 eruption are sketched in Figure 11. The intense explosive activity and increased magmastatic pressure within the conduits promoted the breaching of the conduit system and extension of a dike to the NE [Marchetti et al., 2009; Neri and Lanzafame, 2009]. The observed SW-NE propagation direction of the dike is consistent with our thermal-camerabased observations of the shifting location and style of activity within the crater terrace, where hot fractures and activity were observed to propagate to the NE in the hours prior to the onset of effusion (Figures 11a and 11b). Dikes extending from the central conduit fed effusive vents in the same location during the 1985-1986 and 2002-2003 eruptions [De Fino et al., 1988; Calvari et al., 2005a, 2005b]. Thus, the NE flank of the crater terrace currently appears to be prone to failure during times of increased activity and magmastatic pressure.
[46] In addition to the propagation direction of the eruptive fissure and location of the initial effusive vent, a number of other similarities were observed between the opening phases of the 2002-2003 and those of the 2007 effusive eruptions. For example, as in 2002-2003, openings of effusive vents were heralded by landslides spreading along the SDF. These formed the dust clouds apparent in Figures 3-5. These landslides were also detected by the INGV-OV seismic network [Martini et al., 2007] and can be considered among the precursors of effusive activity and opening of effusive vents at Stromboli. Effusion thus typically begins with a short, high-effusion-rate peak as the central conduit is tapped, followed by a longer waning period over which small variations in effusion can be observed. As previously discussed for Stromboli by Lodato et al. [2007] and Harris et al. [2005b], both the long and the short time scales of variation have implications for the magma dynamics of the shallow system. For example, following Wadge [1981], the short waxing and long waning phase observed in the effusion rate trend can be interpreted as tapping of a pressurized source. However, the effusion rate variations were not smooth; the front of FL3 showed pulsating movements and stopped a short time before the opening of vent 2 (Figures $5 \mathrm{a}$ and $5 \mathrm{~b}$ ). We interpret this behavior as the result of small variations of magma level within the feeder dike during its propagation, forcing shortterm variations in the effusion rate from that dike (Figures $11 \mathrm{c}$ and $11 \mathrm{~d})$.

[47] As during 2002-2003, high effusion rates at the onset of the eruption led to rapid drainage of the shallow system and triggered summit collapses. Collapses propagated to the NE along the feeder dike, causing blockage of vent 2 , which stopped erupting on the afternoon of 8 March (Figure 11e). This probably caused an accumulation of magma and overpressure in the upper conduit, resulting in the opening of a new vent (vent 3 ) at the $550 \mathrm{~m}$ elevation on the following day (Figures 8 and 11e). The position of vent 3 was very close to the conduit, where a similar sequence of vent opening was observed at the onset of the 2002-2003 effusive eruption [Calvari et al., 2005a, 2005b]. The blockage in the feeder dike must have been removed quite quickly, because vent 3 erupted for less than $24 \mathrm{~h}$, with activity at vent 2 resuming on the following day and lasting until the end of the eruption (Figure 11f).

[48] But why was the main active vent during 2007 as low as $400 \mathrm{~m}$ asl, whereas in 1975, 1985-1986, and 2002-2003 the main active vent was located at 500-550, 650, or $670 \mathrm{~m}$ asl? We believe that there is a simple explanation for this. The 2002-2003 eruption began with small volume flank failures that left a collapse scar in the SDF [Bonaccorso et al., 2003]. The eastern margin of the SDF continued a sliding movement after the 2002-2003 eruption [Tommasi et al., 2005, 2008; Bonforte et al., 2008], with greater displacement in the upper part of the SDF and smaller velocities at the lowest benchmarks [Bonforte et al., 2008]. This likely resulted from the formation of a sliding block whose SE margin was used by the intrusion of the 2007 dike (Figures 12a and 12b). We thus suggest that the 2007 dike opened along the sliding surface (marked by the dotted yellow line in Figures 11d-11f and by the dotted green line in Figure 12b) and that both vent 2 and vent 3 formed at the intersection between the topographic 
Table 2. Cumulative Volumes Calculated From Advanced Very High Resolution Radiometer (AVHRR), Moderate Resolution Imaging Spectroradiometer (MODIS), and Forward Looking Infrared (FLIR) Data

\begin{tabular}{|c|c|c|c|c|c|c|c|}
\hline \multirow[b]{2}{*}{ Date $(\mathrm{dd} / \mathrm{mm})$} & \multirow[b]{2}{*}{ Time UTC } & \multicolumn{2}{|c|}{ AVHRR cumulative volume $\left(10^{6} \mathrm{~m}^{3}\right)$} & \multicolumn{2}{|c|}{ MODIS cumulative volume $\left(10^{6} \mathrm{~m}^{3}\right)$} & \multicolumn{2}{|c|}{ FLIR cumulative volume $\left(10^{6} \mathrm{~m}^{3}\right)$} \\
\hline & & Maximum & Minimum & Maximum & Minimum & Maximum & Minimum \\
\hline $27 / 02$ & 1630 & & & & & 1.01 & 0.33 \\
\hline $27 / 02$ & 2006 & 1.40 & 0.56 & & & & \\
\hline $27 / 02$ & 2100 & & & 1.31 & 0.27 & & \\
\hline $28 / 02$ & 0115 & & & 1.57 & 0.33 & & \\
\hline $28 / 02$ & 0830 & & & & & 1.75 & 0.59 \\
\hline $02 / 03$ & 0800 & & & & & 2.94 & 1.03 \\
\hline $04 / 03$ & 1015 & & & 5.54 & 1.17 & 3.82 & 1.30 \\
\hline $04 / 03$ & 2131 & 6.23 & 2.51 & & & & \\
\hline $05 / 03$ & 0101 & 6.26 & 2.52 & & & & \\
\hline $05 / 03$ & 0800 & & & & & 4.08 & 1.38 \\
\hline $06 / 03$ & 0040 & & & 5.92 & 1.25 & & \\
\hline $06 / 03$ & 0941 & 6.69 & 2.70 & & & & \\
\hline $06 / 03$ & 1000 & & & & & 4.27 & 1.43 \\
\hline $06 / 03$ & 1226 & 6.72 & 2.71 & & & & \\
\hline $07 / 03$ & 1130 & & & & & 4.44 & 1.48 \\
\hline $07 / 03$ & 1630 & & & & & 4.47 & 1.49 \\
\hline $08 / 03$ & 0800 & & & & & 4.59 & 1.52 \\
\hline 09/03 & 0830 & & & & & 4.76 & 1.56 \\
\hline $10 / 03$ & 0830 & & & & & 4.89 & 1.59 \\
\hline $11 / 03$ & 0055 & & & 7.48 & 1.58 & & \\
\hline $11 / 03$ & 0830 & & & & & 5.03 & 1.62 \\
\hline $11 / 03$ & 1730 & & & & & 5.09 & 1.63 \\
\hline $11 / 03$ & 2029 & 7.71 & 3.11 & & & & \\
\hline $11 / 03$ & 2125 & & & 7.75 & 1.64 & & \\
\hline $12 / 03$ & 0125 & & & 7.77 & 1.64 & & \\
\hline $12 / 03$ & 0900 & & & & & 5.19 & 1.66 \\
\hline $12 / 03$ & 2020 & & & 7.82 & 1.65 & & \\
\hline $13 / 03$ & 0030 & & & 7.83 & 1.66 & & \\
\hline $13 / 03$ & 0900 & & & & & 5.26 & 1.67 \\
\hline $13 / 03$ & 1255 & 8.06 & 3.26 & & & & \\
\hline $13 / 03$ & 2100 & & & 8.03 & 1.70 & & \\
\hline $14 / 03$ & 0109 & 8.28 & 3.35 & & & & \\
\hline $14 / 03$ & 0115 & & & 8.10 & 1.71 & & \\
\hline $14 / 03$ & 0900 & & & & & 5.37 & 1.70 \\
\hline $14 / 03$ & 2100 & 8.32 & 3.36 & & & & \\
\hline $15 / 03$ & 0058 & 8.32 & 3.36 & & & & \\
\hline $15 / 03$ & 1200 & & & & & 5.49 & 1.73 \\
\hline $15 / 03$ & 2027 & 8.38 & 3.38 & & & & \\
\hline $16 / 03$ & 0730 & & & & & 5.58 & 1.75 \\
\hline $16 / 03$ & 1025 & 8.45 & 3.41 & & & & \\
\hline $16 / 03$ & 1224 & 8.47 & 3.42 & & & & \\
\hline $16 / 03$ & 2014 & 8.57 & 3.47 & & & & \\
\hline $17 / 03$ & 0037 & 8.60 & 3.48 & & & & \\
\hline $17 / 03$ & 1030 & & & & & 5.71 & 1.78 \\
\hline $25 / 03$ & 0730 & & & & & 6.46 & 1.95 \\
\hline $26 / 03$ & 0700 & & & & & 6.55 & 1.97 \\
\hline $26 / 03$ & 0954 & 9.57 & 3.88 & & & & \\
\hline $26 / 03$ & 1045 & & & & & 6.57 & 1.97 \\
\hline $26 / 03$ & 1221 & 9.58 & 3.89 & & & & \\
\hline $26 / 03$ & 1400 & & & & & 6.59 & 1.98 \\
\hline $26 / 03$ & 2123 & 9.62 & 3.91 & & & & \\
\hline $27 / 03$ & 2100 & 9.74 & 3.95 & & & & \\
\hline $27 / 03$ & 2125 & & & 13.3 & 2.81 & & \\
\hline $28 / 03$ & 0030 & & & 13.3 & 2.82 & & \\
\hline $28 / 03$ & 0045 & & & 13.3 & 2.82 & & \\
\hline $28 / 03$ & 1201 & 9.83 & 3.99 & & & & \\
\hline $28 / 03$ & 2037 & 9.87 & 4.01 & & & & \\
\hline $29 / 03$ & 0045 & & & 13.6 & 2.87 & & \\
\hline $30 / 03$ & 1400 & & & & & & \\
\hline $31 / 03$ & 2100 & & & 14.3 & 3.02 & & \\
\hline $31 / 03$ & 2108 & 10.2 & 4.14 & & & & \\
\hline $01 / 04$ & 0115 & & & 14.3 & 3.03 & & \\
\hline $01 / 04$ & 0124 & 10.2 & 4.15 & & & & \\
\hline $01 / 04$ & 1250 & 10.3 & 4.17 & & & & \\
\hline $01 / 04$ & 2045 & 10.3 & 4.19 & & & & \\
\hline
\end{tabular}



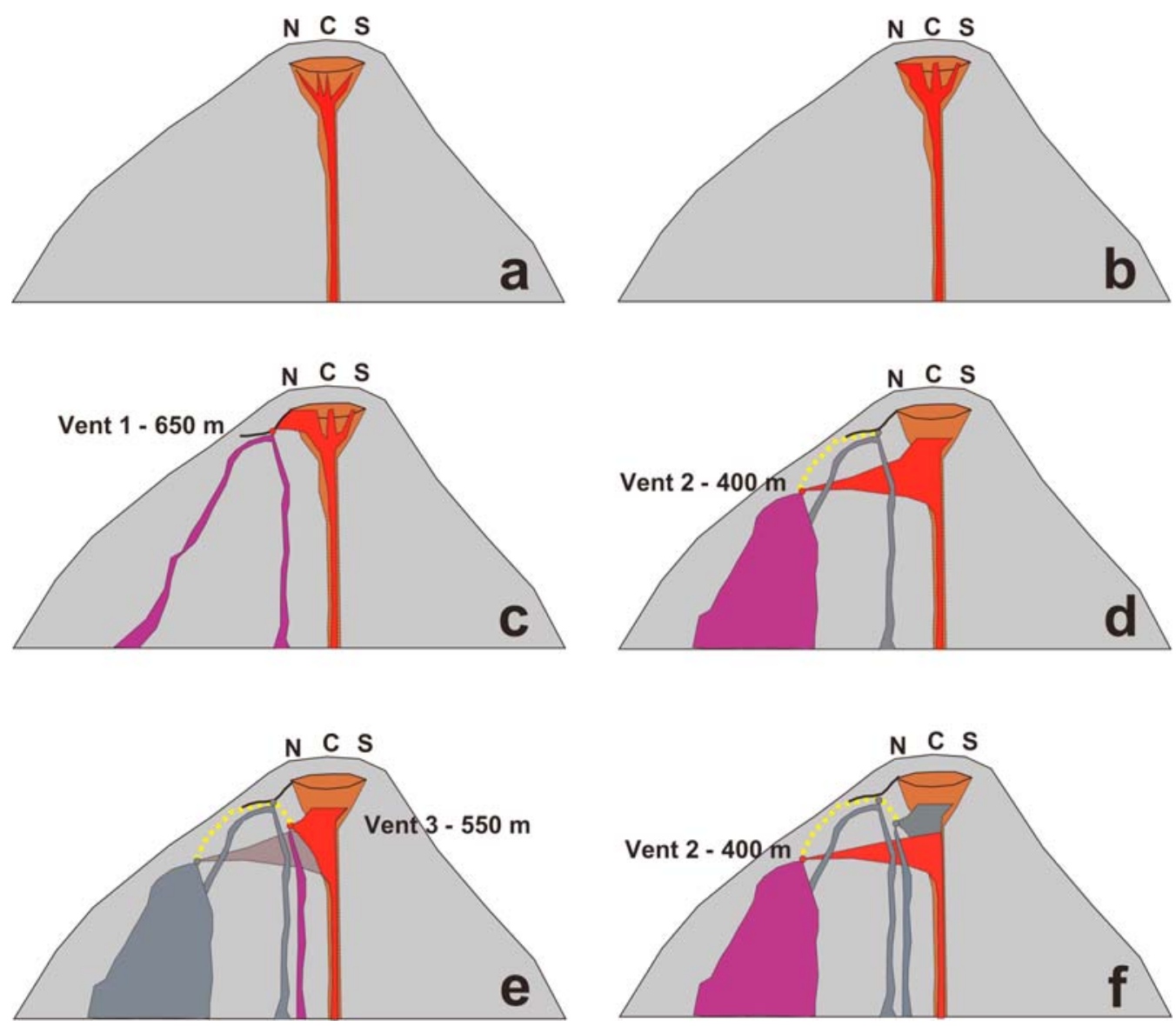

Figure 11. Cross-section sketches of Stromboli (viewed from the north) summarizing our interpretation of the chronology of the 2007 effusive eruption. (a) Enhanced magma and gas flux (red) ascends the conduit (brown) during the weeks preceding the onset of the effusive eruption. N, C, and S mark the NE, central, and SW craters, respectively. (b) The eruptive fissure opens within the NE crater owing to increased magmastatic pressure. (c) The eruptive fissure intersects the NE flank of the crater terrace (black line), and vent 1 (red circle) opens at $650 \mathrm{~m}$ asl to produce a lava flow (purple) that extends to the sea. (d) Magma level within the conduit drops so that vent 1 and its lava flow become inactive (dark gray). The feeder dike propagates downslope along the detachment surface beneath the sliding portion of the SDF (dotted yellow line). Vent 2 opens at $400 \mathrm{~m}$ asl to feed lava flow (purple) to the sea. (e) Effusion rate at vent 2 declines until the vent closes. Magma level within the feeder dike backs up (along the line of the detachment surface; dotted yellow line), and vent 3 reopens at $550 \mathrm{~m}$ to feed lava flow to the sea. (f) Magma level within the conduit drops, causing vent 3 to close (gray). Magma fills the feeder dike so that vent 2 becomes active and lava spreads from this vent to the sea.

slope and the eastern and western margins of the sliding block, respectively (Figures 11d-11f, 12b).

[49] Effusion rates were higher than during the 2002-2003 effusive eruption, as seen from the mean output rates, which were $0.32 \pm 0.28 \mathrm{~m}^{3} \mathrm{~s}^{-1}$ during the 2002-2003 eruption [Lodato et al., 2007], as opposed to $\sim 2.4 \mathrm{~m}^{3} \mathrm{~s}^{-1}$ during the 2007 eruption. The lower elevation of the main effusive vent during the 2007 eruption, that is, $400 \mathrm{~m}$ asl in 2007, compared with 550-670 $\mathrm{m}$ during 2002-2003, may have caused the higher effusion rates during 2007. The increased hydrostatic head resulting from the lower vent elevation in 2007 may, for example, have resulted in higher effusion rates during the initial tapping and drainage of the shallow system. Conduit drainage may, in turn, have been responsible for depressurization of the system, facilitating uprise of gas-rich magma to cause the 15 March paroxysm. Such depressurization is consistent with ground deformation data that were revealed by continuous deflation during the entire 2007 eruption [Bonaccorso et al., 2009].

[50] The 15 March 2007 paroxysm itself was very similar to that of 5 April 2003. The main similarities are as follows.

[51] 1. Both paroxysms occurred after a phase of no explosive activity at the summit craters due to conduit emptying during an effusive eruption.

[52] 2. Both began with a short phase of lithic ash emission.

[53] 3. During both paroxysms, explosive activity propagated from the NE crater to the SW crater with time.

[54] 4. Both events involved the eruption of lithics, highporphyric scoria, and low-porphyric pumice [Bertagnini et al., 1999; Francalanci et al., 2008; Landi et al., 2009]. 

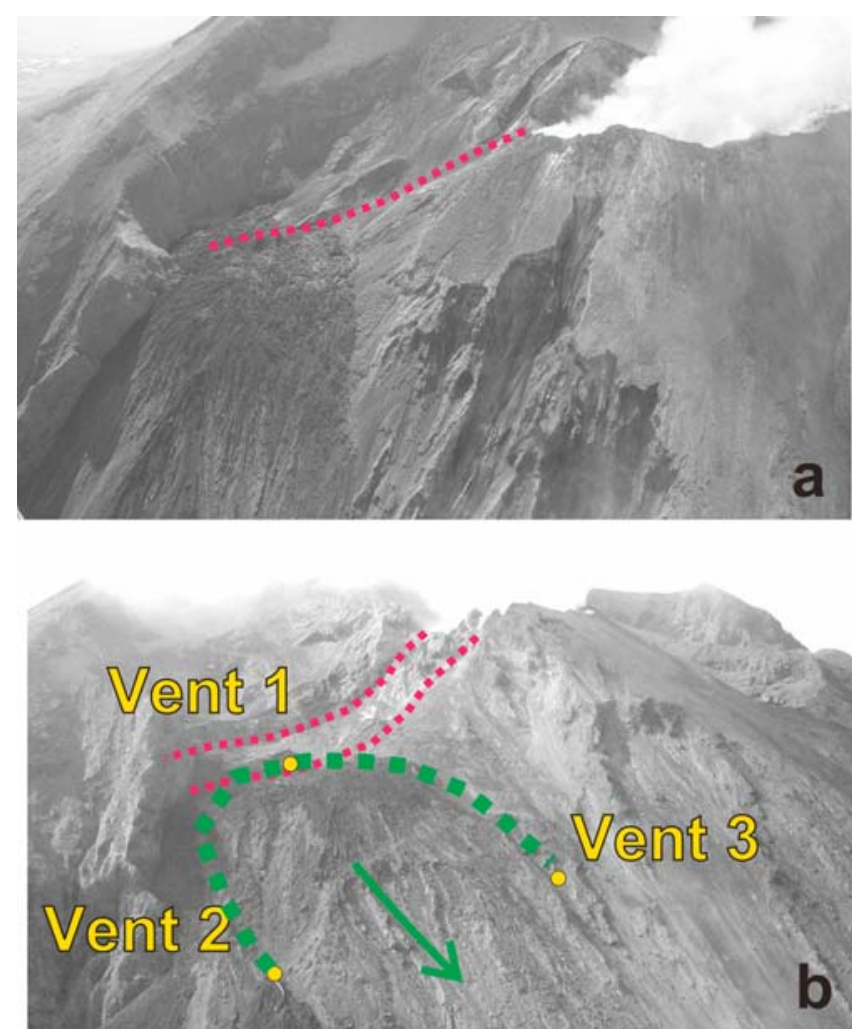

Figure 12. (a) Photo taken in August 2003 showing the crater terrace (source of white steam at top right) and the eruptive fissure (dotted red line) that opened on the NE flank of the crater terrace during the 2002-2003 effusive eruption. (b) Photo taken in June 2007 from the NE, showing the two eruptive fissures (dotted red lines) that opened during the 2007 effusive eruption. The positions of vents 1,2 , and 3 are also marked (yellow circles). The uppermost fissure in Figure $12 \mathrm{~b}$ is interpreted as the reactivation of the 2002-2003 fissure, whereas the lower vents form on the upper boundary of a block that had been sliding since the start of the 2002-2003 effusive eruption. The dotted green line marks the boundary of the sliding block, and the green arrow shows its direction of movement. The 2007 effusive vents $(1,2$, and 3; yellow circles) are located along the intersection of the sliding block with topography.

[55] 5. Both events had similar durations, with the 5 April 2003 event lasting 6-9 $\min$ [Calvari et al., 2006; Harris et al., 2008] and the 15 March 2007 event lasting 7 min.

[56] 6. Both events comprised several eruptive pulses.

[57] However, the 15 March 2007 event was characterized by fire fountaining that formed distinct columns over each of the three crater zones, as was well visible from the SQT400 camera (Figure 9). In comparison, thermal and digital camera data for the 5 April 2003 paroxysm revealed pulsating ash columns [Calvari et al., 2006]. Also, prior to the 5 April 2003 paroxysm, Calvari et al. [2006] recorded an increase in maximum apparent temperature within the crater terrace. No significant increase in the maximum apparent temperature was detected within the crater terrace before the paroxysm of 2007. However, distance and viewing angle may be significant factors in preventing the detection of subtle temperature variations within the crater terrace, especially when consid- ering data from cameras that do not have a view into the craters, as is the case for the SQT400 camera.

\section{Concluding Remarks}

[58] The 2007 effusive eruption of Stromboli showed features similar to those observed during the previous effusive event of 2002-2003. Both eruptions began after a precursory phase of increasing explosive activity and were heralded by a peak in the number of explosions per hour at the summit craters. Both eruptions began with the opening of an eruptive fissure on the NE flank of the crater terrace, and both involved paroxysms that occurred during lava effusion. However, some important differences were observed in 2007: (1) the opening of two parallel fissures on the NE flank of the crater terrace; (2) a lower elevation $(400 \mathrm{~m})$ of the main effusive vent; and (3) a higher mean output rate, which was an order of magnitude higher than those of the two previous eruptions (1985-1986 and 2002-2003).

[59] We suggest that these differences were influenced by the structural dynamics of the SDF, which had been sliding between the 2002-2003 and the 2007 eruptions [Tommasi et al., 2005, 2008; Bonforte et al., 2008]. Opening of vents 1,2 , and 3 occurred at the intersection between the SDF slope and the upper, eastern, and western margins of the sliding block, respectively. In addition, the lower elevation of the 2007 main effusive vent likely caused faster drainage and depressurization of the shallow system and facilitated uprise of the batch of magma that caused the March 2007 paroxysmal event.

[60] Acknowledgments. We wish to thank S. Cocina of the Protezione Civile Regionale Siciliana for promptly making available the helicopter for thermal surveys; the pilot G. Maurici and his team for the many flights carried out during the initial phases of the eruption under harsh and difficult conditions; G. Bertolaso and the Protezione Civile Nazionale for their assistance and support during the whole eruption, and the helicopter pilots C. Geri, C. Cullurà, S. Princiotta, E. Zanetti, L. Laudadio, and L. Zanazzo. Special thanks go to our INGV colleagues from Sezione di Catania, Napoli, Palermo, Pisa, Roma, and Milano, who helped with data collection during the eruption, and, especially, to G. Lanzafame and M. Neri for the fruitful discussions on the mechanisms of opening of eruptive fissures and to M. Neri for creating Figure 1. We wish to thank the former Director of INGV, Sezione di Catania, A. Bonaccorso, for his continuous encouragement and support of our activities. This work was possible thanks to the installation and maintenance of the INGV-CT Web-camera network carried out by E. Pecora, E. Biale, D. Condarelli, and D. Reitano. This paper was partially supported by a grant to S. Calvari (Project INGV-DPC Paroxysm V2/03, 2008-2010) funded by the Istituto Nazionale di Geofisica e Vulcanologia and by the Italian Civil Protection. Satellite-based effusion rate work by A. Steffke and A. Harris was supported by NASA grant NNG04GO64G ("New Tools for Advanced Hot Spot Tracking"). The authors wish to thank the reviewers M. James, M. Patrick, R. Arculus, and L. Glaze for their many suggestions that greatly improved the paper.

\section{References}

Andronico, D., A. Cristaldi, and J. Taddeucci (2007), Eruzione Stromboli 2007: Evento parossistico del 15 marzo, INGV-CT Report, Prot. Int., UFVG2007(116), pp. 1-7, Istituto Nazionale di Geofisica e Vulcanologia, Sezione di Catania, Catania, Italy.

Bailey, J. E., A. J. L. Harris, J. Dehn, S. Calvari, and S. K. Rowland (2006), The changing morphology of an open lava channel on Mt. Etna, Bull. Volc., 68(6), 497-515, doi:10.1007/s00445-005-0025-6.

Ball, M., and H. Pinkerton (2006), Factors affecting the accuracy of thermal imaging cameras in volcanology, J. Geophys. Res., 111, B11203, doi:10. 1029/2005JB003829.

Barberi, F., M. Rosi, and A. Sodi (1993), Volcanic hazard assessment at Stromboli based on review of historical data, Acta Vulc., 3, 173-187. 
Barberi, F., L. Civetta, M. Rosi, and R. Scandone (2009), Chronology of the 2007 eruption of Stromboli and the activity of the Scientific Synthesis Group, J. Volc. Geoth. Res., 182, 123-130, doi:10.1016/j.jvolgeores. 2008.09 .019$.

Bertagnini, A., M. Coltelli, P. Landi, M. Pompilio, and M. Rosi (1999), Violent explosions yield new insights into dynamics of Stromboli volcano, Eos Trans. $A G U, 80(52)$, 633-636, doi:10.1029/99EO00415.

Bonaccorso, A., S. Calvari, G. Garfi, L. Lodato, and D. Patané (2003), December 2002 flank failure and tsunami at Stromboli volcano inferred by volcanological and geophysical observations, Geophys. Res. Lett., 30(18), 1941, doi:10.1029/2003GL017702.

Bonaccorso, A., A. Bonforte, S. Gambino, M. Mattia, F. Guglielmino, G. Puglisi, and E. Boschi (2009), Insight on recent Stromboli eruption inferred from terrestrial and satellite ground deformation measurements, J. Volc. Geoth. Res., doi:10.1016/j.jvolgeores.2009.01.007.

Bonforte, A., M. Aloisi, G. Antonello, N. Casagli, J. Fortuny-Guash L. Guerri, G. Nunnari, G. Puglisi, A. Spata, and D. Tarchi (2008), Movements of the Sciara del Fuoco, in The Stromboli Volcano: An Integrated Study of the 2002-2003 Eruption, edited by S. Calvari et al., AGU Geophysical Monograph Series, 182, 183-200.

Burton, M. R., S. Calvari, L. Spampinato, L. Lodato, N. A. Pino, E. Marchetti, and F. Murè (2008), Volcanic and seismic activity at Stromboli preceding the 2002-2003 eruption, in The Stromboli Volcano: An Integrated Study of the 2002-2003 Eruption, edited by S. Calvari et al., AGU Geophysical Monograph Series, 182, 93-104.

Calvari, S., and H. Pinkerton (1998), Formation of lava tubes and extensive flow field during the 1991-93 eruption of Mount Etna, J. Geophys. Res., 103(B11), 27,291-27,302, doi:10.1029/97JB03388

Calvari, S., and H. Pinkerton (2004), Birth, growth and morphologic evolution of the "Laghetto" cinder cone during the 2001 Etna eruption, J. Volc. Geoth. Res., 132, 225-239, doi:10.1016/S0377-0273(03) 00347-0

Calvari, S., M. Neri, and H. Pinkerton (2003), Effusion rate estimations during the 1999 summit eruption on Mt. Etna, and growth of two distinct lava flow fields. J. Volc. Geoth. Res., 119, 107-123, doi:10.1016/S0377200273(02)00308-6.

Calvari, S., L. Spampinato, L. Lodato, A. J. L. Harris, M. R. Patrick J. Dehn, M. R. Burton, and D. Andronico (2005a), Chronology and complex volcanic processes during the 2002-2003 flank eruption at Strombol volcano (Italy) reconstructed from direct observations and surveys with a handheld thermal camera, J. Geophys. Res., 110, B02201, doi:10.1029/ 2004JB003129

Calvari, S., L. Spampinato, L. Lodato, A. J. L. Harris, M. R. Patrick, J. Dehn, M. R. Burton, and D. Andronico (2005b), Correction to "Chronology and Complex Volcanic Processes During the 2002-2003 Flank Eruption at Stromboli Volcano (Italy) Reconstructed From Direct Observations and Surveys With a Handheld Thermal Camera," J. Geophys. Res., 110, B02201, doi:10.1029/2004JB003129.

Calvari, S., L. Spampinato, and L. Lodato (2006), The 5 April 2003 vulcanian paroxysmal explosion at Stromboli volcano (Italy) from field observations and thermal data, J. Volc. Geoth. Res., 149, 160-175, doi:10. 1016/j.jvolgeores.2005.06.006.

Capaldi, G., et al. (1978), Stromboli and its 1975 eruption, Bull. Volc., 41 (3), 259-285, doi:10.1007/BF02597227.

Casagli, N., A. Tibaldi, A. Merri, C. Del Ventisette, T. Apuani, L. Guerri, J. Fortuny-Guasch, and D. Tarchi (2009), Deformation of Stromboli Volcano (Italy) during the 2007 crisis by radar interferometry, numerical modeling and field structural data, J. Volc. Geoth. Res., 182, 182-200, doi:10.1016/j.jvolgeores.2009.01.002.

Chouet, B., P. Dawson, T. Ohminato, M. Martini, G. Saccorotti, F. Giudicepietro, G. De Luca, G. Milana, and R. Scarpa (2003), Source mechanisms of explosions at Stromboli Volcano, Italy, determined from moment-tensor inversions of very-long-period data, J. Geophys. Res., 108(B1), 2019, doi:10.1029/2002JB001919.

De Fino, M., L. La Volpe, S. Falsaperla, G. Frazzetta, G. Neri, L. Francalanci, M. Rosi, and A. Sbrana (1988), The Stromboli eruption of December 6 , 1985-April 25, 1986: Volcanological, petrological and seismological data, Rend. Soc. It. Min. Petr., 43, 1021-1038.

Dehn, J., A. Harris, and M. Ripepe (2001), Infrared imaging of Strombolian eruptions, Annual AGU Meeting, San Francisco, Calif., USA, December 10-14, 2001.

Dragoni, M., and A. Tallarico (2009), Assumptions in the evaluation of lava effusion rates from heat radiation, Geophys. Res. Lett., 36 , L08302, doi:10.1029/2009GL037411.

Francalanci, L., A. Bertagnini, N. Métrich, A. Renzulli, R. Vannucci, P. Landi, S. Del Moro, M. Menna, C. M. Petrone, and I. Nardini (2008), Mineralogical, geochemical, and isotopic characteristics of the ejecta from the 5 April 2003 paroxysm at Stromboli, Italy: Inferences on the preeruptive magma dynamics, in The Stromboli Volcano: An Integrated Study of the 2002-2003 Eruption, edited by S. Calvari et al., AGU Geophysical Monograph Series, 182, 331-346.

Giudicepietro, F., L. D’Auria, M. Martini, T. Caputo, R. Peluso, W. De Cesare, M. Orazi, and G. Scarpato (2009), Changes in the VLP seismic source during the 2007 Stromboli eruption, J. Volc. Geoth. Res., 182, 162-171, doi:10.1016/j.jvolgeores.2008.11.008.

Harris, A. J. L., and S. M. Baloga (2009), Lava discharge rates from satellite-measured heat flux, Geophys. Res. Lett., 36, L19302, doi:10. 1029/2009GL039717.

Harris, A. J. L., and M. Neri (2002), Volumetric observations during paroxysmal eruptions at Mount Etna: Pressurized drainage of a shallow chamber or pulsed supply? J. Volc. Geoth. Res., 116, 79-95, doi:10. 1016/S0377-0273(02)00212-3.

Harris, A. J. L., and M. Ripepe (2007a), Synergy of multiple geophysical approaches to unravel explosive eruption conduit and source dynamicsA case study from Stromboli, Chem. Erde, 67, 1-35, doi:10.1016/j.chemer. 2007.01.003.

Harris, A. J. L., and M. Ripepe (2007b), Temperature and dynamics of degassing at Stromboli, J. Geophys. Res., 112, B03205, doi:10.1029/ 2006JB004393

Harris, A. J. L., and S. K. Rowland (2009), Effusion rate controls on lava flow length and the role of heat loss: A review, in Studies in Volcanology: The Legacy of George Walker, edited by T. Thordarson et al., Special Publications of IAVCEI, 2, 33-51.

Harris, A. J. L., and D. S. Stevenson (1997), Thermal observations of degassing open conduits and fumaroles at Stromboli and Vulcano using remotely sensed data, J. Volcanol. Geotherm. Res., 76, 175-198, doi:10.1016/ S0377-0273(96)00097-2.

Harris, A. J. L., A. L. Butterworth, R. W. Carlton, I. Downey, P. Miller, P. Navarro, and D. A. Rothery (1997), Low-cost volcano surveillance from space: Case studies from Etna, Krafla, Cerro Negro, Fogo, Lascar and Erebus, Bull. Volc., 59, 49-64, doi:10.1007/s004450050174.

Harris, A. J. L., J. B. Murray, S. E. Aries, M. A. Davies, L. P. Flynn, M. J. Wooster, R. Wright, and D. A. Rothery (2000), Effusion rate trends at Etna and Krafla and their implications for eruptive mechanisms, J. Volc. Geoth. Res., 102, 237-270, doi:10.1016/S0377-0273(00)00190-6.

Harris, A. J. L., J. E. Bailey, S. Calvari, and J. Dehn (2005a), Heat loss measured at a lava channel and its implications for down-channel cooling and rheology, Geol. Soc. Am. Spec. Paper, 396, 125-146.

Harris, A. J. L., J. Dehn, M. Patrick, S. Calvari, M. Ripepe, and L. Lodato (2005b), Lava effusion rates from hand-held thermal infrared imagery: An example from the June 2003 effusive activity at Stromboli, Bull. Volc., 68, 107-117, doi:10.1007/s00445-005-0425-7.

Harris, A. J. L., J. Dehn, and S. Calvari (2007), Lava effusion rate definition, measurement and operational requirements: A review, Bull. Volc. 70, 1-22, doi:10.1007/s00445-007-0120-y.

Harris, A. J. L., M. Ripepe, S. Calvari, L. Lodato, and L. Spampinato (2008), The 5 April 2003 explosion of Stromboli: Timing of eruption dynamics using thermal data, in The Stromboli Volcano: An Integrated Study of the 2002-2003 Eruption, edited by S. Calvari et al., AGU Geophysical Monograph Series, 182, 305-316.

Harris, A. J. L., M. Favalli, F. Mazzarini, and C. W. Hamilton (2009), Construction dynamics of a lava channel, Bull. Volc., 71, 459-474, doi:10. 1007/s00445-008-0238-6.

Hirn, B., C. Di Bartola, and F. Ferrucci (2009), Combined use of SEVIRI and MODIS for detecting, measuring, and monitoring active lava flows at erupting volcanoes, IEEE Trans. Geosci. Remote Sens., 47(8), 2923 2930, doi:10.1109/TGRS.2009.2014224.

James, M., H. Pinkerton, and S. Robson (2007), Image-based measurement of flux variation in distal regions of active lava flows, Geochem. Geophys. Geosyst., 8, Q03006, doi:10.1029/2006GC001448.

Kilburn, C. R. J. (1993), Lava crust, aa flow lengthening and the pahoehoe-aa transition, in Active lavas: Monitoring and Modelling, edited by C. R. J. Kilburn and G. Luongo, pp. 263-279, UCL Press, London.

Landi, P., R.A. Corsaro, L. Francalanci, L. Civetta, L. Miraglia, M. Pompilio, and R. Tesoro (2009), Magma dynamics during the 2007 Stromboli eruption (Aeolian Islands, Italy): Mineralogical, geochemical and isotopic data, J. Volc. Geoth. Res., 182(3/4), 255-268, doi:10.1016/j.jvolgeores.2008. 11.010 .

Lautze, N. C., A. J. L. Harris, J. E. Bailey, M. Ripepe, S. Calvari, J. Dehn, S. Rowland, and K. Evans-Jones (2004), Pulsed lava effusion at Mount Etna during 2001, J. Volc. Geoth. Res., 137, 231-246, doi:10.1016/j.jvolgeores. 2004.05.018.

Lodato, L., L. Spampinato, A. J. L. Harris, S. Calvari, J. Dehn, and M. Patrick (2007), The morphology and evolution of the Stromboli 2002-2003 lLava flow field: An example of Basaltic flow field emplaced on a steep slope, Bull. Volc., 69, 661-679, doi:10.1007/s00445-006-0101-6.

Marchetti, E., R. Genco, and R. Ripepe (2009), Ground deformation and seismicity related to the propagation and drainage of the dyke feeding 
system during the 2007 effusive eruption at Stromboli volcano (Italy), $J$. Volc. Geoth. Res., 182, 155-161, doi:10.1016/j.jvolgeores.2008.11.016.

Martini, M., et al. (2007), Seismological monitoring of the February 2007 effusive eruption of the Stromboli volcano, Ann. Geophys., 50(6), 775-788.

Neri, M., and G. Lanzafame (2009), Structural features of the 2007 Stromboli eruption, J. Volc. Geoth. Res., 182, 137-144, doi:10.1016/j.jvolgeores. 2008.07.021.

Patrick, M. R. (2007), Dynamics of Strombolian ash plumes from thermal video: Motion, morphology, and air entrainment, J. Geophys. Res., 112, B06202, doi:10.1029/2006JB004387.

Patrick, M. R., A. J. L. Harris, M. Ripepe, J. Dehn, D. A. Rothery, and S. Calvari (2007), Strombolian explosive styles and source conditions: Insights from thermal (FLIR) video, Bull. Volc., 69, 769-784, doi:10.1007/ s00445-006-0107-0.

Pioli, L., M. Rosi, S. Calvari, L. Spampinato, A. Renzulli, and A. Di Roberto (2008), The eruptive activity of 28 and 29 December 2002, in The Stromboli Volcano: An Integrated Study of the 2002-2003 Eruption, edited by S. Calvari et al., AGU Geophysical Monograph Series, 182 , 105-116.

Ripepe, M., E. Marchetti, G. Ulivieri, A. J. L. Harris, J. Dehn, M. R. Burton, T. Caltabiano, and G. G. Salerno (2005), Effusive to explosive transition during the 2003 eruption of Stromboli volcano, Geology, 33(5), 341344, doi:10.1130/G21173.1.

Ripepe, M., D. Delle Donne, G. Lacanna, E. Marchetti, and G. Ulivieri (2009), The onset of the 2007 Stromboli effusive eruption recorded by an integrated geophysical network, J. Volc. Geoth. Res., 182, 131-136, doi:10.1016/j.jvolgeores.2009.02.011.

Rosi, M., A. Bertagnini, A. J. L. Harris, L. Pioli, M. Pistolesi, and M. Ripepe (2006), A case history of paroxysmal explosion at Stromboli: Timing and dynamics of the April 5, 2003 event, Earth Planet. Sci. Lett., 243, 594 606, doi:10.1016/j.eps1.2006.01.035.

Rowland, S. K., A. J. L. Harris, M. J. Wooster, F. Amelung, H. Garbeil, L. Wilson, and P. Mouginis-Mark (2003), Volumetric characteristics of lava flows from interferometric radar and multispectral satellite data: The 1995 Fernandina and 1998 Cerro Azul eruptions in the western Galàpagos, Bull. Volc., 65, 311-330, doi:10.1007/s00445-002-0262-x.

Sawyer, G. M., and M. R. Burton (2006), Effects of a volcanic plume on thermal imaging data, Geophys. Res. Lett., 33, L14311, doi:10.1029/ 2005 GL025320.

Scandone, R., F. Barberi, and M. Rosi (2009), The 2007 eruption of Stromboli: Preface, J. Volc. Geoth. Res., 182, v, doi:10.1016/j.jvolgeores.2008.12.019.

Spampinato, L., S. Calvari, A. J. L. Harris, and J. Dehn (2008a), Evolution of the lava flow field, in The Stromboli Volcano: An Integrated Study of the 2002-2003 Eruption, edited by S. Calvari et al., AGU Geophysical Monograph Series, 182, 201-212.

Spampinato, L., S. Calvari, C. Oppenheimer, and L. Lodato (2008b), Shallow magma transport for the 2002-2003 Mt. Etna eruption inferred from thermal infrared surveys, J. Volc. Geoth. Res., 177, 301-312, doi:10.1016/ j.jvolgeores.2008.05.013.

Spinetti, C., M. F. Buongiorno, F. Doumaz, M. Musacchio, V. Lombardo, A. J. L. Harris, A. Steffke, and S. Amici (2007), Rapporto eruzione Stromboli 9-16 marzo 2007, pp. 1-9, http://www.ct.ingv.it/Report/ BollettinoCNT 160307 Stromboli\%20(2).pdf

Tinti, S., A. Manucci, G. Pagnoni, A. Armigliato, and F. Zaniboni (2005), The 30 December 2002 landslide-induced tsunamis in Stromboli: Sequence of the events reconstructed from the eyewitnesses accounts, Nat. Hazards Earth Syst. Sci., 5, 763-775.

Tommasi, P., P. Baldi, F. L. Chiocci, M. Coltelli, M. Marsella, M. Pompilio, and C. Romagnoli (2005), The landslide sequence induced by the 2002 eruption at Stromboli Volcano, in Landslide-Risk Analysis and Sustainable Disaster Management, edited by K. Sassa et al., pp. 251258, Springer-Verlag, Berlin.

Tommasi, P., P. Baldi, F. L. Chiocci, M. Coltelli, M. Marsella, and C. Romagnoli (2008), Slope failures induced by the December 2002 eruption at Stromboli volcano, in The Stromboli Volcano: An Integrated Study of the 2002-2003 Eruption, edited by S. Calvari et al., AGU Geophysical Monograph Series, 182, 129-145.

Wadge, G. (1981), The variation of magma discharge during basaltic eruptions, J. Volc. Geoth. Res., 11, 139-168, doi:10.1016/0377-0273(81) 90020-2.

Washington, H. S. (1917), Persistence of vents at Stromboli and its bearing on volcanic mechanism, Geol. Soc. Am. Bull., 28, 249-278.

Wright, R., S. Blake, A. J. L. Harris, and D. A. Rothery (2001), A simple explanation for the space-based calculation of lava eruption rates, Earth Planet. Sci. Lett., 192, 223-233, doi:10.1016/S0012-821X(01)00443-5.

Zanon, V., M. Neri, and E. Pecora (2009), Interpretation of data from the monitoring thermal camera of Stromboli volcano (Aeolian Islands, Italy), Geol. Mag., 146(4), 591-601, doi:10.1017/S0016756809005937.

E. Boschi, S. Calvari (corresponding author), A. Cristaldi, L. Lodato, and L. Spampinato, Istituto Nazionale di Geofisica e Vulcanologia, Sezione di Catania, Piazza Roma 2, 95123 Catania, Italy. (calvari@ct.ingv.it)

A. J. L. Harris, Laboratoire Magmas et Volcans, Université Blaise Pascal, 5 Rue Kessler, 63038 Clermont Ferrand, France.

A. Steffke, Hawaii Institute of Geophysics and Planetology/School of Ocean and Earth Science and Technology, University of Hawaii, 1680 East West Road, Honolulu, HI 96822, USA. 